\title{
A Versatile Approach to Access Trimetallic Complexes Based on Trisphosphinite Ligands
}

\author{
Juan Miranda-Pizarro, Macarena G. Alférez, M. Dolores Fernández-Martínez, Eleuterio Álvarez ${ }^{\mathbb{D}}$, \\ Celia Maya and Jesús Campos* \\ Instituto de Investigaciones Químicas (IIQ), Departamento de Química Inorgánica and Centro de Innovación en \\ Química Avanzada (ORFEO-CINQA), Consejo Superior de Investigaciones Científicas (CSIC) and University of \\ Sevilla, Avenida Américo Vespucio 49, 41092 Sevilla, Spain; juan.miranda@iiq.csic.es (J.M.-P.); \\ macarena.gonzalez@iiq.csic.es (M.G.A.); mariadolores.fernandez@urv.cat (M.D.F.-M.); ealvarez@iiq.csic.es (E.Á.); \\ maya@us.es (C.M.) \\ * Correspondence: jesus.campos@iiq.csic.es
}

Academic Editor: Barbara Modec

Received: 23 December 2019; Accepted: 23 January 2020; Published: 29 January 2020

check for updates

\begin{abstract}
A straightforward method for the preparation of trisphosphinite ligands in one step, using only commercially available reagents (1,1,1-tris(4-hydroxyphenyl)ethane and chlorophosphines) is described. We have made use of this approach to prepare a small family of four trisphosphinite ligands of formula $\left[\mathrm{CH}_{3} \mathrm{C}\left\{\left(\mathrm{C}_{6} \mathrm{H}_{4} \mathrm{OR}_{2}\right)_{3}\right]\right.$, where $\mathrm{R}$ stands for $\mathrm{Ph}(\mathbf{1 a}), \mathrm{Xyl}\left(\mathbf{1 b}, \mathrm{Xyl}=2,6-\mathrm{Me}_{2}-\mathrm{C}_{6} \mathrm{H}_{3}\right)$, ${ }^{i} \operatorname{Pr}(\mathbf{1 c})$, and $\mathrm{Cy}(\mathbf{1 d})$. These polyfunctional phosphinites allowed us to investigate their coordination chemistry towards a range of late transition metal precursors. As such, we report here the isolation and full characterization of a number of $\mathrm{Au}(\mathrm{I}), \mathrm{Ag}(\mathrm{I}), \mathrm{Cu}(\mathrm{I}), \mathrm{Ir}(\mathrm{III}), \mathrm{Rh}(\mathrm{III})$ and $\mathrm{Ru}(\mathrm{II})$ homotrimetallic complexes, including the structural characterization by X-ray diffraction studies of six of these compounds. We have observed that the flexibility of these trisphosphinites enables a variety of conformations for the different trimetallic species.
\end{abstract}

Keywords: phosphinite; multidentate ligands; polymetallic; supramolecular chemistry; trimetallic; coordination polymer

\section{Introduction}

The design of new classes of multidentate ligands has attracted much attention over the previous decades in the context of supramolecular chemistry. Owing to the rigidity and predictable geometries adopted by nitrogen and oxygen donors, those have been primarily selected to construct well-defined self-assembled architectures relying on metal-ligand coordination [1-5]. In contrast, multidentate phosphines have been explored to a lesser extent, despite the prominent position that their monovalent versions occupy in organometallic chemistry and homogeneous catalysis. Regardless of their more limited use, the unique features that polydentate phosphines offer (i.e., superior flexibility, irregular topologies, chirality, ${ }^{31} \mathrm{P}$ NMR analysis), have led to a rich variety of supramolecular structures derived from metal coordination [6], including cages [7-10], porous solids [11,12], helicates [13,14], coordination polymers [15-17], and even a chiral nanocluster [18]. Besides, many of these polymetallic structures reveal a remarkable capacity for molecular recognition and sensing $[19,20]$, interesting photochemical properties [21-24], or catalytic applications [25].

With all this in mind, it is somehow surprising that related multidentate phosphinites have barely been investigated. Phosphinites $\left(\mathrm{PR}_{2}(\mathrm{OR})\right)$ were identified as valuable ligands long after the widespread use of phosphines. Their superior $\pi$-acceptor ability confers the resulting metal complexes distinctive electronic features that have been broadly exploited for catalytic applications $[26,27]$. Besides, the reduced $\sigma$-donating capacity of phosphinites compared to phosphines 
may facilitate accessing well-defined supramolecular structures in a more selective manner by dynamic coordination-dissociation behavior in solution. In addition, multidentate phosphinites could be further exploited for anchoring homogeneous catalysts to oxide surfaces $[28,29]$ by one or several of their $\mathrm{PR}_{2}(\mathrm{OR})$ functionalities. The use of polypodal phosphorus ligands is particularly appealing in this context [30].

To the best of our knowledge, the limited number of multidentate phosphinite systems capable of binding more than two metals [31] mostly rely on the chemistry of functionalized calixarenes [32-35], with clear catalytic potential [36]. In a more recent study, a triruthenium complex constructed around a tridentate aminophosphine-phosphinite ligand was recognized as an efficient homogenous catalyst in transfer hydrogenation reactions [37]. To better understand the chemistry of these underdeveloped systems, we decided to synthesize several homotrimetallic complexes stabilized by a family of tridentate phosphinites. An additional advantage of phosphinites, compared to more traditional phosphines, is the easiness of the experimental procedures by which these ligands can be prepared. Polydentate phosphines are laborious to synthesize, often lack selectivity, and require the use of highly reactive reagents [9,38-42]. In stark contrast, we report herein a simple and versatile method to prepare several tridentate phosphinites by common procedures [43], in one-step, and from commercially available reagents. The coordination chemistry of these ligands, with a range of transition metal precursors, is also described.

\section{Results and Discussion}

\subsection{Synthesis of Tripodal Phosphinites}

We have focused on a family of trisphosphinites derived from the condensation of commercially available and affordable 1,1,1-tris(4-hydroxyphenyl)ethane, with several chlorophosphines under basic conditions in good yields (63-84\%; Scheme 1). This method contrasts with traditional approaches for the preparation of trisphosphines, which require several synthetic steps and the use of aggressive reagents [9,38-42]. The synthetic procedure is highly versatile and permits the incorporation of phosphines bearing both aliphatic and aromatic substituents, including sterically congested functionalities, such as the two xylyl (2,6- $\left.-\mathrm{Me}_{2}-\mathrm{C}_{6} \mathrm{H}_{3}\right)$ groups per phosphorus center in trisphosphinite $\mathbf{1} \mathbf{b}$. While trisphosphinites 1a and 1c could be readily prepared using triethylamine as the base, after overnight stirring, ligands derived from the bulkier halophosphines $\mathrm{PCl}(\mathrm{Xyl})_{2}$ and $\mathrm{PClCy}_{2}$ required the use of sodium hydride and longer reaction times. Trisphosphinites $\mathbf{1 a}-\mathbf{d}$ were fully characterized by multinuclear NMR spectroscopy (see Section 3 and Supplementary Materials for details). A single ${ }^{31} \mathrm{P}\left\{{ }^{1} \mathrm{H}\right\} \mathrm{NMR}$ resonance at around 112 ppm was recorded for trisphosphinites $\mathbf{1 a}$ and $\mathbf{1} \mathbf{b}$ bearing aromatic substituents, while it shifted to higher frequencies (ca. $146 \mathrm{ppm}$ ) for $\mathbf{1 c}$ and $\mathbf{1 d}$, as expected for phosphinite ligands with aliphatic fragments. To avoid oxidation and increase the overall yield of the trimetallic transition metal complexes, these ligands were typically used after its formation without further purification. However, we managed to grow single crystals of the more sterically congested ligand of the family (1b) that were suitable for X-ray diffraction studies. The corresponding ORTEP diagram is depicted in Figure 1 and evinces the C3 geometry of the trisphosphinite. The $\mathrm{P}-\mathrm{O}$ bond distances account for around $1.66 \AA$, while the $\mathrm{P}-\mathrm{O}-\mathrm{C}_{\mathrm{Ar}}$ angles are not identical, varying from $117.50(15)^{\circ}(\mathrm{C} 28-\mathrm{O} 2-\mathrm{P} 2)$ to $123.18(15)^{\circ}(\mathrm{C} 50-\mathrm{O} 3-\mathrm{P} 3)$, though the differences do not seem significant. 


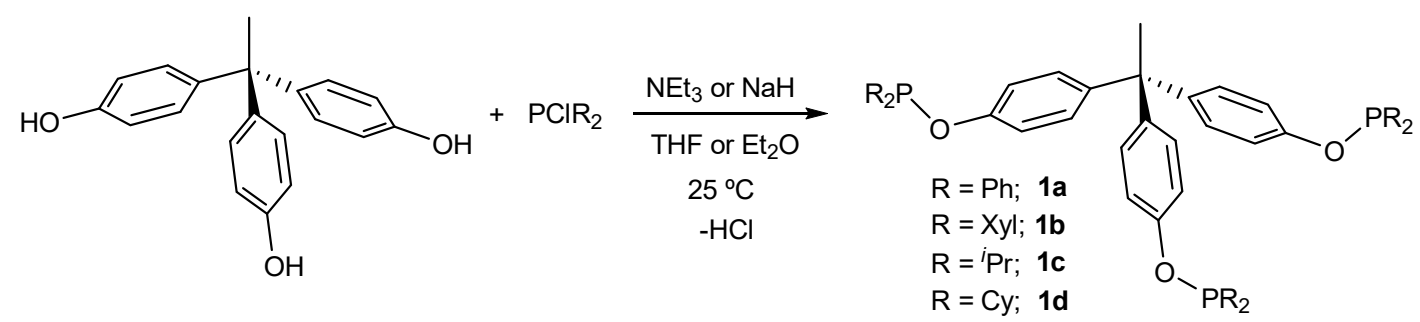

Scheme 1. Synthesis of trisphosphinite ligands from 1,1,1-tris(4-hydroxyphenyl)ethane and dihalophosphines.

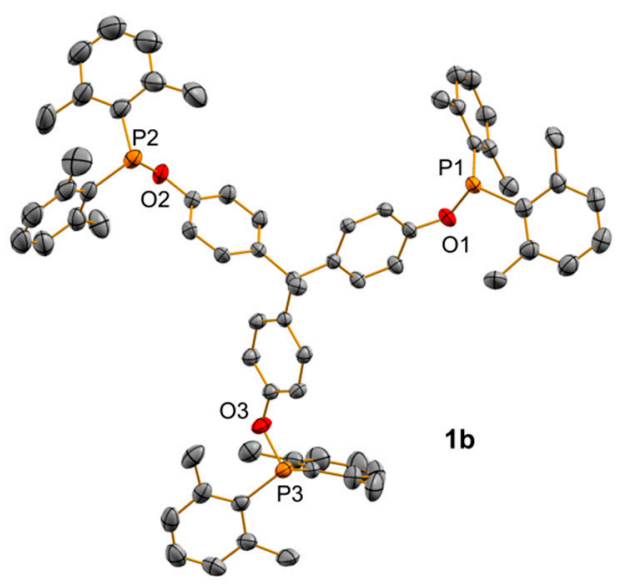

Figure 1. ORTEP view of the solid structure of compound $\mathbf{1 b}$ with thermal ellipsoids set at $50 \%$ probability. Hydrogen atoms have been excluded for the sake of clarity.

\subsection{Synthesis and Characterization of Trimetallic Complexes}

Many of the reported supramolecular structures built over polydentate phosphines contain rigid backbones. The introduction of those rigid cores, such as a phenyl or triazine ring to which the phosphorus centers are directly bound, has permitted the design of trimetallic synthons to construct more complex supramolecular structures in a predictable manner [6]. Besides, the C3-symmetry of those systems can be used to attain genuinely chiral cages [44]. The C3-trisphosphinites prepared herein introduce an additional degree of structural flexibility that could be an advantage to search for unusual patterns of self-assembly or to access novel supramolecular architectures. However, before entering into that matter, it is necessary to better understand the coordination chemistry of trisphosphinites $\mathbf{1}$. To do so, we decided to prepare a series of trimetallic complexes derived from common late transition-metal precursors.

The reaction of 1a with group 11 metal precursors in a 1:3 molar ratio produced the corresponding trimetallic complexes (Scheme 2). The reaction between $\mathbf{1 a}$ and $[\mathrm{AuCl}(\mathrm{THT})]$ (THT = tetrahydrothiophene) in dichloromethane yielded $\left[\mathrm{CH}_{3} \mathrm{C}\left\{\left(\mathrm{C}_{6} \mathrm{H}_{4} \mathrm{OPPh}_{2}\right) \mathrm{AuCl}_{3}\right](\mathbf{2 a})\right.$ as an air-stable white powder in excellent isolated yield (95\%). Following a similar procedure, the related silver compound $\left[\mathrm{CH}_{3} \mathrm{C}\left\{\left(\mathrm{C}_{6} \mathrm{H}_{4} \mathrm{OPPh}\right)_{3} \mathrm{Ag}(\mathrm{OTf})\right\}_{3}\right](3 \mathrm{a})\left(\mathrm{OTf}^{-}=\mathrm{OSO}_{2} \mathrm{CF}_{3}{ }^{-}\right.$; triflate) was isolated in $72 \%$ yield by using AgOTf as the metal precursor. This species was less stable than $\mathbf{2 a}$ under ambient conditions, though it could be handled under air for moderate periods of time. At variance, reaction with $\mathrm{CuCl}$, led to the formation of an insoluble white solid upon concentration of the resulting dichloromethane solution under vacuum. This may result from the formation of a coordination polymer (4a) based on the binding of two phosphinite ligands to each of the copper atoms, as previously reported for polydentate phosphines [45-48], and even for a related bisphosphinite ligand [49]. This solid could be conveniently washed with hexane and dissolved in $\mathrm{CDCl}_{3}$ to be characterized by NMR spectroscopy, though subtle variations in temperature or concentration caused the formation of less tractable viscous solutions. Distinctive ${ }^{31} \mathrm{P}\left\{{ }^{1} \mathrm{H}\right\}$ NMR resonances were recorded at 112.8 (2a), 120.6 (3a), and 96.1 (4a) 
ppm, in agreement with previous related compounds [49,50], while ${ }^{1} \mathrm{H}$ NMR spectra did not reveal unusual patterns. A distinctive feature that remains constant along all the compounds studied in this work is the decrease in the scalar coupling constant ${ }^{1} J_{\mathrm{CP}}$ of the carbon centers directly bound to the phosphorus nuclei upon metal coordination. Thus, while this value accounts for $18 \mathrm{~Hz}$ in $\mathbf{1 a}$, it drastically increases in the corresponding trimetallic species $(\mathbf{2 a}, 70 \mathrm{HZ} ; \mathbf{3 a}, 38 \mathrm{~Hz} ; \mathbf{4 a}, 81 \mathrm{~Hz})$. Interestingly, ${ }^{1} \mathrm{H},{ }^{1} \mathrm{H}$ NOESY studies support the proposed polymeric structure of $4 \mathbf{a}$ (Figure 2). As expected, compounds $\mathbf{2 a}$ and $3 \mathbf{a}$ exhibit a single correlation peak of opposite phase to the diagonal signals that connect the apical methyl group of the ligand backbone and one of the aromatic protons of the three $O$-phenyl rings. At variance, compound 4 a reveals several cross peaks that couple the same methyl group with all aromatic signals of the ${ }^{1} \mathrm{H}$ NMR spectrum (Figure 2). Moreover, those correlation peaks present the same sign as the diagonal signals [51], altogether supporting the notion of $4 \mathbf{a}$ as a polymeric structure.

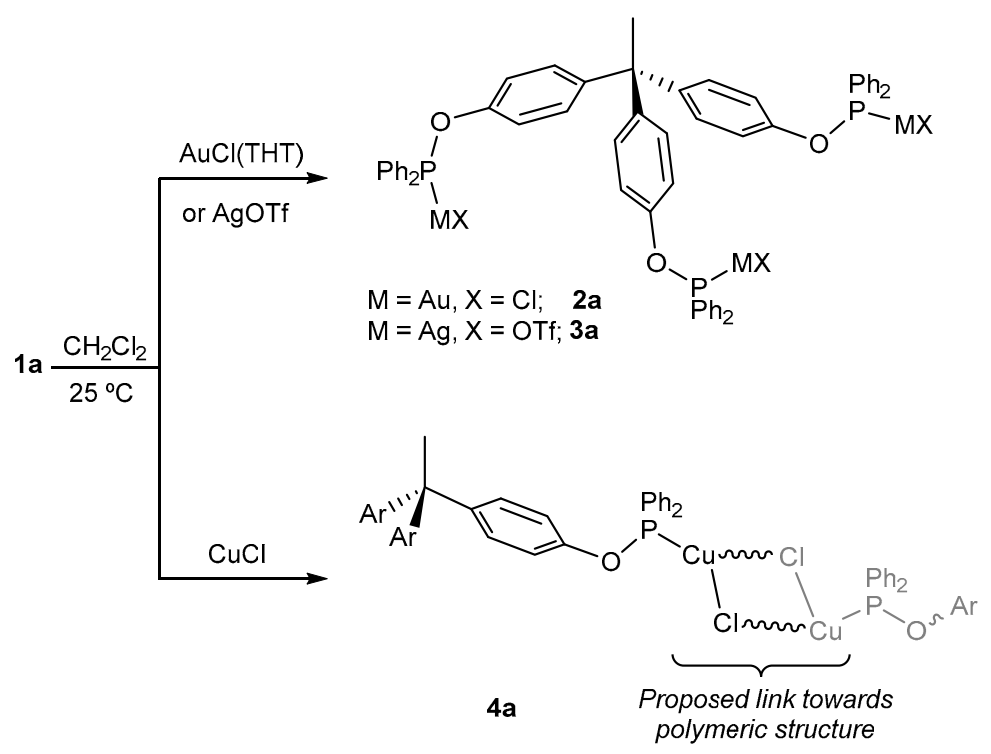

Scheme 2. Synthesis of gold (2a) and silver (3a) trimetallic complexes, and suggested coordination polymer structure of the copper based compound $\mathbf{4 a}$, based on trisphosphinite $\mathbf{1 a}$.

The molecular structure of $\mathbf{2 a}$ was further authenticated by X-ray diffraction studies after its crystallization by slow diffusion of pentane over a benzene solution of the compound. Its ORTEP diagram is depicted in Figure 3a. The flexibility of the trisphosphinite is evinced by the different orientations adopted by the $\mathrm{Au}-\mathrm{Cl}$ termini as a result of the rotation along the $\mathrm{C}-\mathrm{O}$ and $\mathrm{O}-\mathrm{P}$ bonds. Thus, the three gold centers appear completely alternate, at variance with the free ligand $\mathbf{1 b}$ (Figure 1 ), where the orientation of the three lone pairs is convergent [9]. The three $\mathrm{P}-\mathrm{Au}-\mathrm{Cl}$ fragments display normal bond distances, and the expected linear orientation, without any significant distortion (ca.

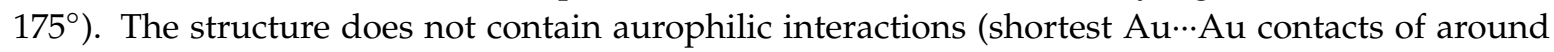
$4.28 \AA$ ), but the presence of weak $\mathrm{C}-\mathrm{H} / \pi$ interactions led to the one-dimensional supramolecular chain along the $a$ axis represented in Figure $3 \mathrm{~b}$. Each trigold molecule is connected to another two along the a direction by two $\mathrm{C}-\mathrm{H} / \pi$ interactions characterized by $\mathrm{H} \cdots \mathrm{C}\left(\mathrm{sp}^{2}\right)$ distances of around $2.74 \AA$, as well as $d_{\mathrm{H} \cdots \text { centroid }}$ from 3.37 to $3.60 \AA$; and $\mathrm{C}-\mathrm{H} \cdots$ centroid angles between 122 and $131^{\circ}$. 

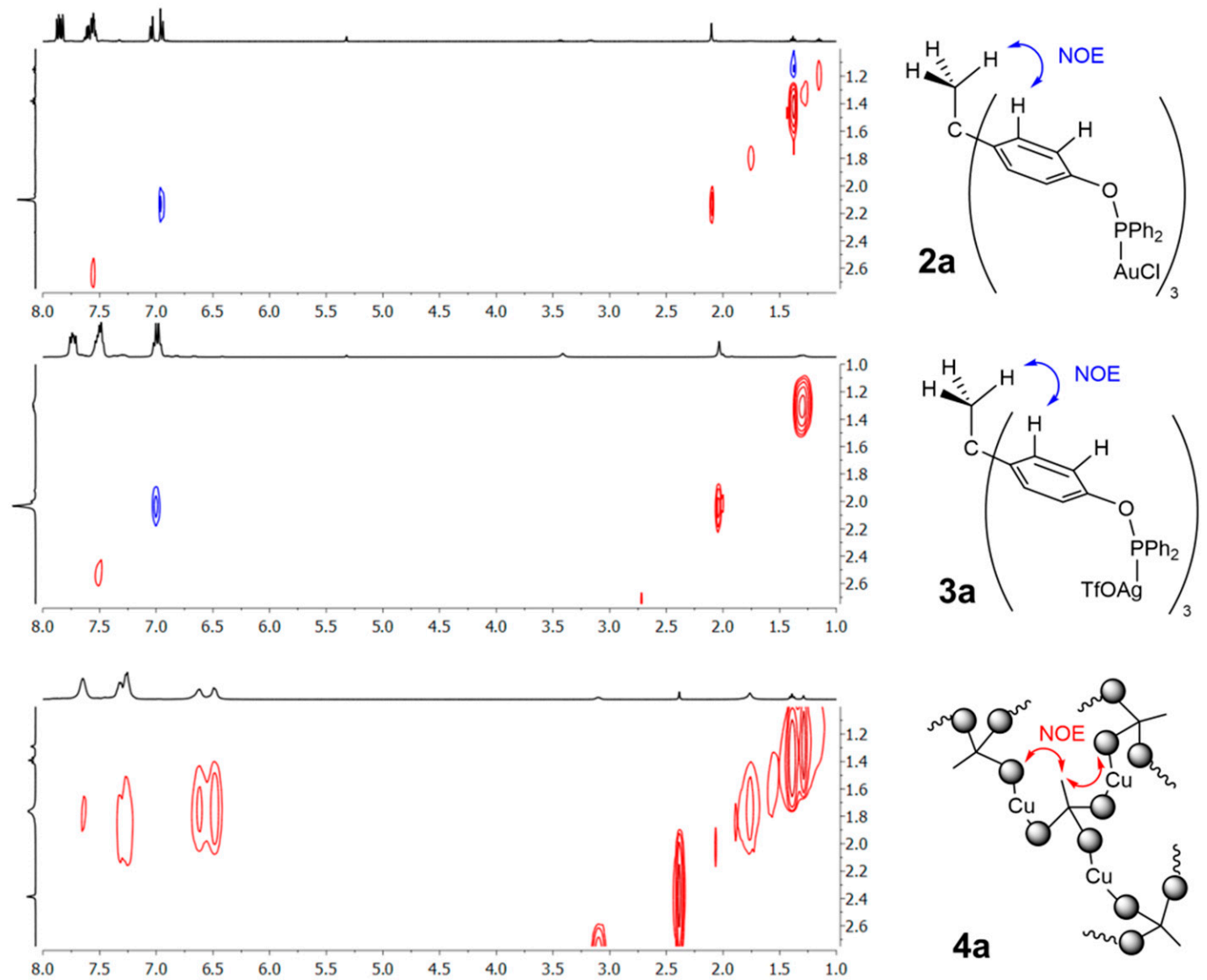

Figure 2. ${ }^{1} \mathrm{H},{ }^{1} \mathrm{H}$ NOESY experiments of compounds 2a, 3a, and $\mathbf{4 a}$. Grey balls in $4 \mathbf{a}$ represent $\mathrm{C}_{6} \mathrm{H}_{4}-\mathrm{O}-\mathrm{PPh}_{2}$ moieties.

(a)

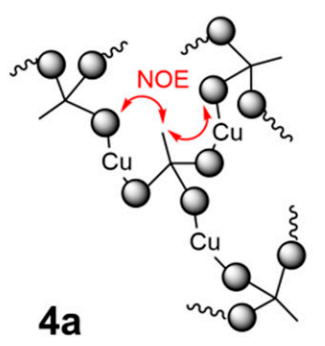

4a

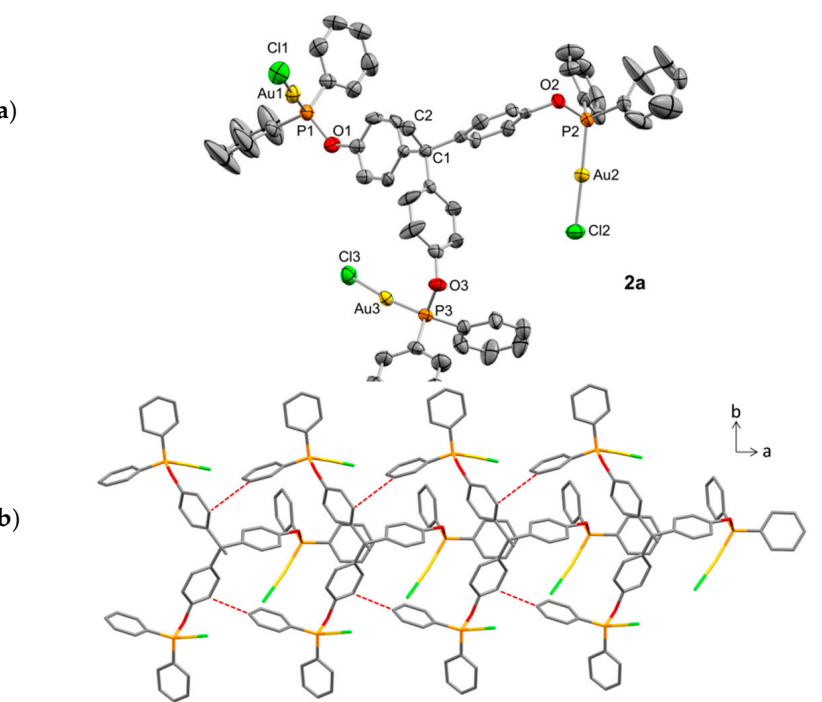

Figure 3. (a) ORTEP view of the solid structure of compound 2a with thermal ellipsoids set at $50 \%$ probability. Hydrogen atoms have been excluded for the sake of clarity. Selected bond distances $(\AA)$ and angles $\left({ }^{\circ}\right)$ : Au1-P1, 2.214(3); Au1-Cl1, 2.279(4); Au2-P2, 2.228(3); Au2-Cl2, 2.290(3); Au3-P3, 2.219(3); Au3-Cl3, 2.277(3); P1-O1, 1.631(8); P2-O2, 1.621(7); P3-O3, 1.618(8); P1-Au1-Cl1, 177.66(13); P2-Au2-Cl2, 173.51(11); P3-Au3-Cl3, 177.91(11); O1-P1-Au1, 114.0(3); O2-P2-Au2, 111.0(3); O3-P3-Au3, 115.0(3); (b) intermolecular weak C $-\mathrm{H} / \pi$ interactions (red dotted lines) that produce 1D supramolecular chains of $\mathbf{2 a}$ along [ $\left[\begin{array}{lll}1 & 0 & 0\end{array}\right]$. 
To gain further insights into the coordination chemistry of trisphosphinite 1a, we next focused our attention on other common late transition metal precursors. Reactions of 1a with $\left[\left(\eta^{5}-\mathrm{C}_{5} \mathrm{Me}_{5}\right) \mathrm{MCl}_{2}\right]_{2}(\mathrm{M}=\mathrm{Rh}, \mathrm{Ir})$ and $\left[\mathrm{Ru}(p \text {-cymene }) \mathrm{Cl}_{2}\right]_{2}$ produced the corresponding trimetallic compounds $\left[\mathrm{CH}_{3} \mathrm{C}\left\{\left(\mathrm{C}_{6} \mathrm{H}_{4} \mathrm{OPPh}_{2}\right) \mathrm{Rh}\left(\eta^{5}-\mathrm{C}_{5} \mathrm{Me}_{5}\right) \mathrm{Cl}_{2}\right\}_{3}\right](5 \mathrm{a}),\left[\mathrm{CH}_{3} \mathrm{C}\left\{\left(\mathrm{C}_{6} \mathrm{H}_{4} \mathrm{OPPh}\right) \operatorname{Ir}\left(\eta^{5}-\mathrm{C}_{5} \mathrm{Me}_{5}\right) \mathrm{Cl}_{2}\right\}_{3}\right]$ (6a), and $\left[\mathrm{CH}_{3} \mathrm{C}\left\{\left(\mathrm{C}_{6} \mathrm{H}_{4} \mathrm{OPPh}_{2}\right) \mathrm{Ru}\left(p \text {-cymene) } \mathrm{Cl}_{2}\right\}_{3}\right]\right.$ (7a) in moderate to good yields (Scheme 3). In contrast, reaction with either $\left[\mathrm{Pt}(\mathrm{dmso})_{2} \mathrm{Cl}_{2}\right]$ or $\left[\mathrm{Pt}\left(\mathrm{SMe}_{2}\right)_{2} \mathrm{Cl}_{2}\right]$ did not lead to clean reaction products, whereas precursors $\left[\mathrm{Pd}\left(\mathrm{C}_{6} \mathrm{H}_{5} \mathrm{CN}\right)_{2} \mathrm{Cl}_{2}\right]$ and $\left[\mathrm{Pd}(\mathrm{COD}) \mathrm{Cl}_{2}\right](\mathrm{COD}=1,5$-cyclooctadiene) yielded 8a resulting from $\mathrm{C}-\mathrm{O}$ bond cleavage at trisphenol $1 \mathrm{a}$ in the presence of adventitious water, as previously reported for a related system [49].

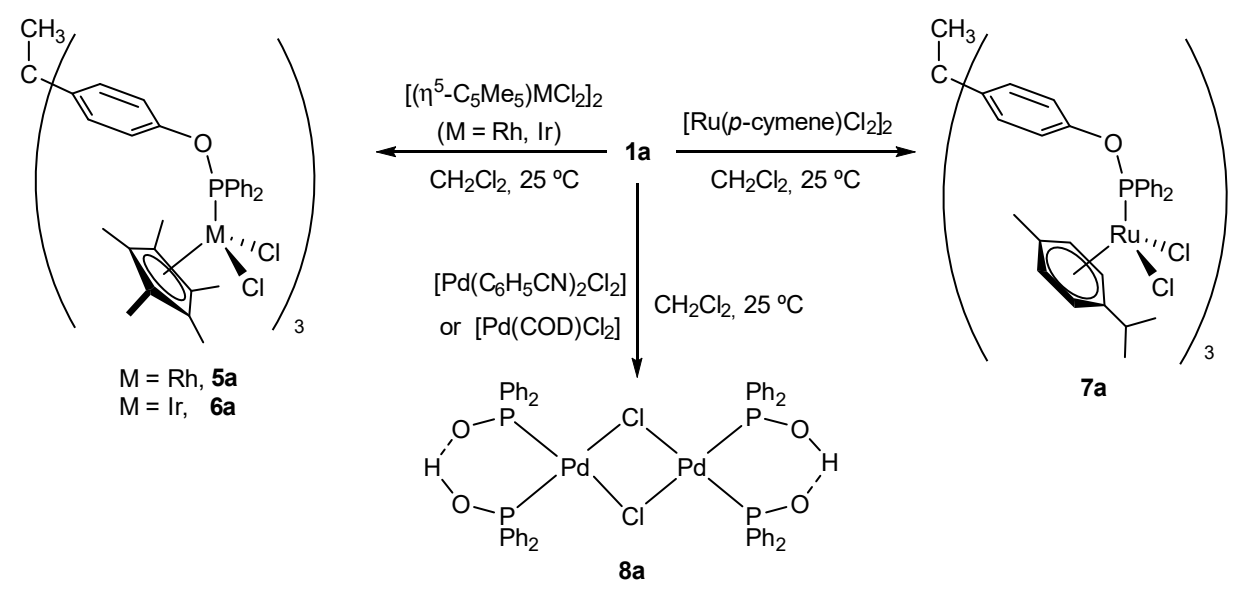

Scheme 3. Reaction of trisphosphinite 1a with several common late transition metal precursors.

Coordination of the rhodium and ruthenium precursors to 1a did not lead to a significant variation of the ${ }^{31} \mathrm{P}\left\{{ }^{1} \mathrm{H}\right\}$ NMR spectra of the resulting complexes, which displays resonances at $c a .114 \mathrm{ppm}(c . f$. $110.5 \mathrm{ppm}$ for 1a). Nevertheless, coordination of the rhodium precursor was evinced by a strong scalar coupling to phosphorus, with the ${ }^{31} \mathrm{P}\left\{{ }^{1} \mathrm{H}\right\}$ signal appearing as a doublet $\left({ }^{1} J_{\mathrm{PRh}}=170 \mathrm{~Hz}\right)$ for $5 \mathbf{a}$. In turn, the ${ }^{31} \mathrm{P}\left\{{ }^{1} \mathrm{H}\right\}$ resonance of the triiridium complex $6 \mathbf{a}$ appeared considerably downshifted at $72.3 \mathrm{ppm}$. As discussed above, formation of the trimetallic species could be additionally inferred from an increase (ca. $30-60 \mathrm{~Hz}$ ) of the values of the scalar coupling $\left({ }^{1} J_{\mathrm{CP}}\right)$ observed for the ${ }^{13} \mathrm{C}\left\{{ }^{1} \mathrm{H}\right\}$ NMR resonances arising from the carbon atoms directly bound to the phosphorus nuclei. Other spectroscopic features can be consulted in the Section 3.

The molecular formulation of these three complexes was further confirmed by X-ray diffraction studies (Figure 4). Suitable crystals of compounds $\mathbf{5 a}$ and $\mathbf{6 a}$ were grown from slow diffusion of diethyl ether into their dichloromethane solutions at $-30^{\circ} \mathrm{C}$, whereas crystals of $7 \mathbf{a}$ were obtained from diffusion of pentane into a dichloromethane/acetone solution of the compound at the same temperature. The C3-symmetry of the three complexes is crystallographically maintained, with the three structures grown in trigonal space groups (i.e., $P-3$ for $5 \mathbf{a}$ and $\mathbf{6 a} ; R 3$ for $7 \mathbf{a}$ ). At variance with the structure of the trigold compound $\mathbf{2 a}$, the orientation of the three $\mathrm{P}-\mathrm{M}$ fragments is convergent, with all the metal units pointing to the opposite direction of the $\mathrm{C}-\mathrm{CH}_{3}$ terminus, which also contrasts with the free ligand 1a (Figure 1), where the phosphine lone pairs are oriented towards the opposite direction. As occurs in the structure of $\mathbf{2 a}$, there are no metal-metal interactions, either intra- or intermolecularly (all intermetallic distances $>4.5 \AA$ ). Bond angles and distances lie within normal values for monovalent phosphinite complexes of these metals. The structures of $5 \mathbf{a}$ and $\mathbf{6 a}$ are basically equal, with $\mathrm{P}-\mathrm{O}$ bond distances of $1.63 \AA$ and $\mathrm{M}-\mathrm{P}$ lengths of 2.283(2) and 2.261(2) $\AA$, respectively. The $\mathrm{M}-\mathrm{P}-\mathrm{O}$ are also almost identical, with values of $116.16(14)(5 \mathbf{a}), 115.89(16)(\mathbf{6 a})$, and $115.2(3)^{\circ}$ (7a). As expected, the iso-propyl groups of the cymene fragments in $7 \mathbf{a}$ are oriented away from the $C 3$ rotation axis to reduce steric constraints. 


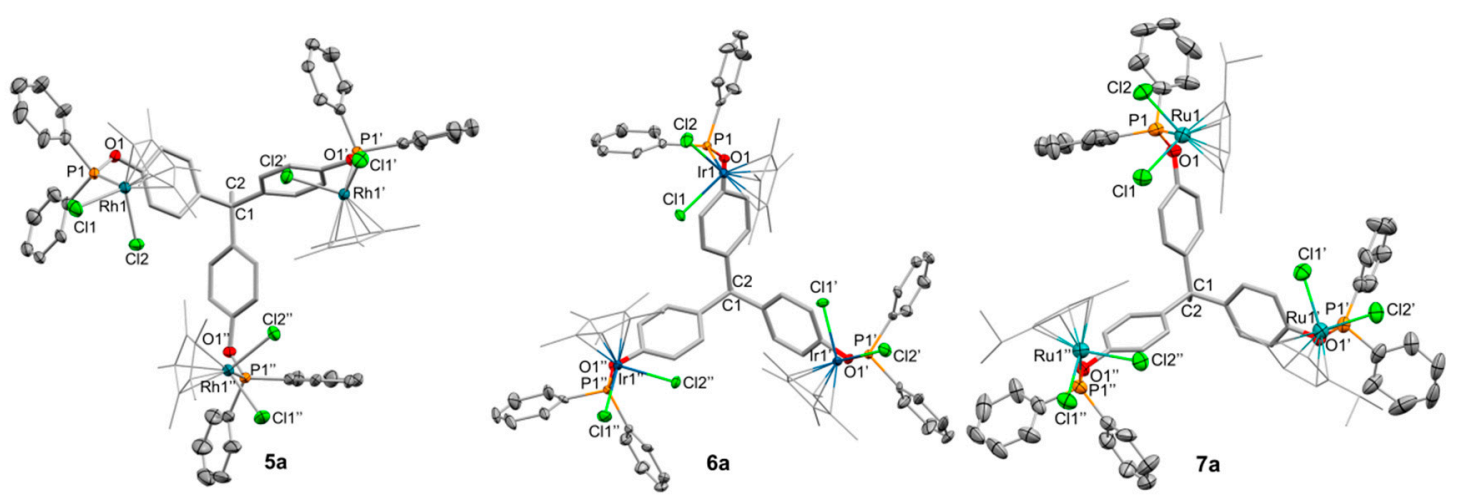

Figure 4. ORTEP view of the solid structure of compounds $\mathbf{5 a}, \mathbf{6 a}$, and $\mathbf{7 a}$ with thermal ellipsoids set at $50 \%$ probability. Hydrogen atoms and solvent molecules have been excluded for the sake of clarity. Selected bond distances $(\AA)$ and angles $\left({ }^{\circ}\right)$ : Compound 5a: Rh1-P1, 2.2829(16); Rh1-Cl1, 2.3945(15); Rh1-Cl2, 2.4017(16); P1-O1, 1.619(4); P1-Rh1-Cl1, 95.44(5); C1-Rh1-Cl2, 155.27(17); P1-Rh1-Cl2, 91.64(6); Cl1-Rh1-Cl2, 88.57(6); Compound 6a: Ir1-P1, 2.2611(17); Ir1-Cl1, 2.4047(13); Ir1-C12, 2.4114(15); P1-O1, 1.625(5); C1-C2, 1.581(14); C1-Ir1-P1, 111.11(18); P1-Ir1-Cl1, 95.92(5); P1-Ir1-Cl2, 92.08(6); O1-P1-Ir1, 115.89(16); Compound 7a (selected from the two independent molecules in the asymmetric unit): Ru1-P1, 2.305(3); Ru1-Cl2, 2.403(3); Ru1-Cl1, 2.418(3); Ru2-P2, 2.300(3); Ru2-Cl4, 2.410(3); Ru2-Cl3, 2.414(3); P1-O1, 1.637(7); P2-O2, 1.651(7); C2-C1, 1.550(19); P1-Ru1-Cl2, 82.72(9); P1-Ru1-Cl1, 92.94(9); Cl2-Ru1-Cl1, 88.98(10); P2-Ru2-Cl4, 82.69(9); P2-Ru2-Cl3, 93.08(9); Cl4-Ru2-Cl3, 88.89(10); O1-P1-Ru1, 114.7(3); O2-P2-Ru2, 115.3(3).

Despite the high similarity of the molecular structures of compounds $\mathbf{5 a}, \mathbf{6} \mathbf{a}$, and $\mathbf{7 a}$, the pattern of weak interactions that define their crystal packing differs considerably. For $\mathbf{5 a}$ and $\mathbf{7 a}$, the trimetallic molecules are not interconnected by direct interactions, instead the presence of considerable amounts of solvent molecules prevents the establishment of an extended covalent network. However, the presence of numerous $\pi-\pi$ stacking and $\mathrm{C}-\mathrm{H} / \pi$ interactions in the solid-state structure of 6a gives rise to well-defined $a b$ layers of triiridium complexes (Figure 5). An initial analysis shows that each trimetallic motif is connected to three other adjacent ones by two $\pi-\pi$ interactions between $\eta^{5}-\mathrm{C}_{5} \mathrm{Me}_{5}$ and phenyl phosphinite rings, as well as two weak $\mathrm{C}-\mathrm{H} / \pi$ interactions between one $\mathrm{sp}^{3}$ $\mathrm{CH}$ group of the cyclopentadienyl fragments, and a contiguous phenyl ring. Thus, this pattern gives rise to hexagonal periodic motifs that form the aforementioned $a b$ layers. The $\pi-\pi$ interactions are characterized by a centroid-centroid distance of 3.772(5) $\AA$, with a plane-plane angle of $11.53(9)^{\circ}$ and an offset angle of $6.23(7)^{\circ}$ [52]. In turn, the $\mathrm{C}-\mathrm{H} / \pi$ contacts are defined by a shortest $\mathrm{H} \cdots \mathrm{C}\left(\mathrm{sp}^{2}\right)$ distance of 2.900(6) $\AA$; $d_{\mathrm{H} \cdots \text { centroid }}$ of 3.13(1) $\AA$; and $\mathrm{C}-\mathrm{H} \cdots$ centroid angle of $106.5(5)^{\circ}$, the latter indicating that these interactions are particularly weak $[53,54]$.

To probe the coordination ability of the reported trisphosphinite ligands $\mathbf{1}$, we chose precursor $\left[\left(\eta^{5}-\mathrm{C}_{5} \mathrm{Me}_{5}\right) \mathrm{IrCl}_{2}\right]_{2}$ to prepare the corresponding trimetallic complexes $\mathbf{6 b}-\mathbf{d}$ (Scheme 4$)$. Following the same experimental procedure that led us to isolate $\mathbf{6 a}$ we could have access to compounds $\mathbf{6 c}$ and $\mathbf{6 d}$ in excellent yields (ca. 85\%). In contrast, targeting $\mathbf{6 b}$ proved more challenging, and produced a complex mixture of products as evinced by multinuclear NMR analysis, which could be attributed to both steric reasons and to the possibility of phosphine cyclometalation through one or several of the benzylic methyl groups of the xylyl rings, as previously observed in related compounds based on the $\left[\left(\eta^{5}-\mathrm{C}_{5} \mathrm{Me}_{5}\right) \mathrm{Ir}\right]$ moiety [55-58]. Nevertheless, we could isolate the corresponding trigold complex $\left[\mathrm{CH}_{3} \mathrm{C}\left\{\left(\mathrm{C}_{6} \mathrm{H}_{4} \mathrm{OP}(\mathrm{Xyl})_{2}\right) \mathrm{AuCl}_{3}\right](\mathbf{2 b})\right.$ by reaction between $\mathbf{1 b}$ and $[\mathrm{AuCl}(\mathrm{THT})]$, the latter being less sterically congested than the iridium precursor and non-amenable to $\mathrm{C}\left(\mathrm{sp}^{3}\right)-\mathrm{H}$ cyclometalation. These complexes were characterized by microanalysis and multinuclear NMR spectroscopy, with data in agreement with the previously discussed iridium and gold complexes. 


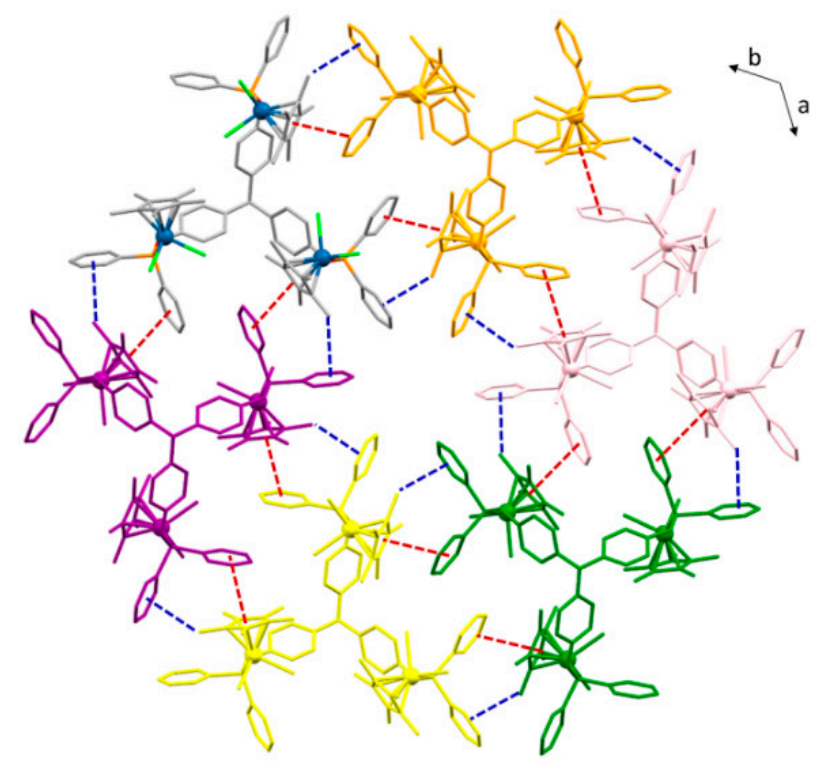

Figure 5. Projection of the crystal structure of $6 \mathbf{a}$ along [ $\left[\begin{array}{lll}0 & 0 & 1\end{array}\right]$ highlighting intermolecular $\pi-\pi$ (red dotted lines) and $\mathrm{C}-\mathrm{H} / \pi$ (blue dotted lines) interactions between triiridium compounds. Each molecule of $\mathbf{6 a}$ has been highlighted in different colors for clarity, while metal centers are represented as balls.

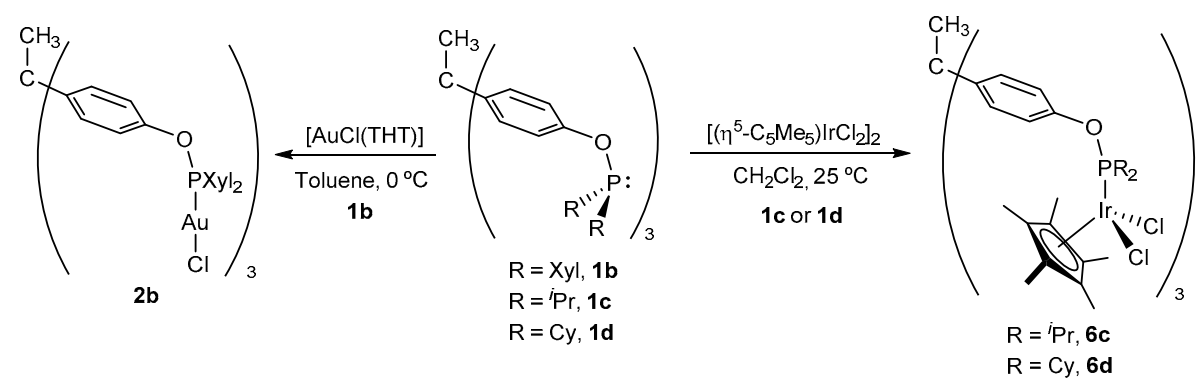

Scheme 4. Synthesis of trimetallic complexes based on trisphosphinite ligands $\mathbf{1 b}-\mathbf{d}$.

Single crystals of good quality were grown for compounds $\mathbf{6 c}$ and $\mathbf{6 d}$ by pentane/chloroform diffusion and toluene evaporation, respectively. Those permitted us to further corroborate their molecular formulation by X-ray diffraction analysis (Figure 6). Bond angles and distances are comparable to those in compound $\mathbf{6 a}$ and do not require further discussion. Interestingly, the structure of $\mathbf{6 d}$, along with that of $\mathbf{2 a}$, are the only ones within this work that present alternate configurations of the phosphinite moieties in the solid state. While one of the $\mathrm{O}-\mathrm{P}$ vectors in $\mathbf{6} \mathbf{d}$ points away from the $\mathrm{C}-\mathrm{CH}_{3}$ direction ('torsion angle' of $135.8^{\circ}$ ), in the same manner as in the rest of trimetallic structures of this work, the other two $\mathrm{O}-\mathrm{P}$ bonds are placed in an alternate fashion ('torsion angles' of 43.5 and $57.2^{\circ}$ ). It seems that this peculiar rearrangement does not involve the establishment of new intramolecular weak interactions, but it certainly demonstrates the flexibility of the multidentate ligands reported in this work, even after coordination of three metal fragments. 

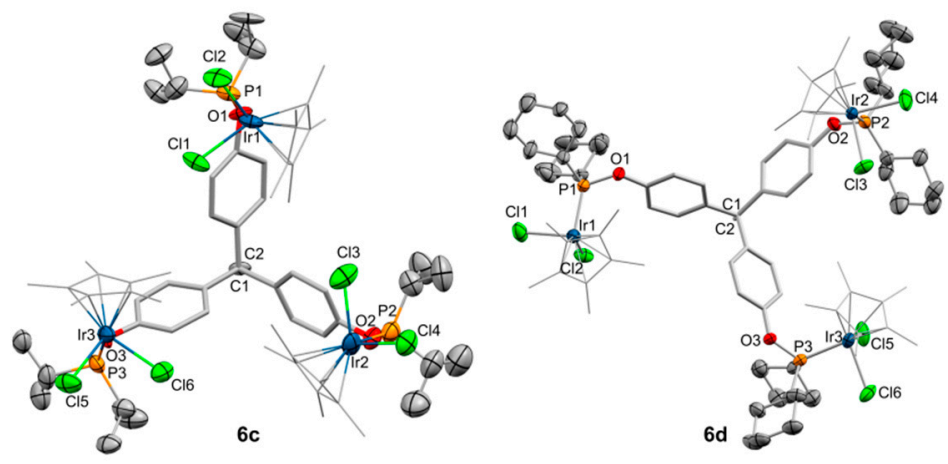

Figure 6. ORTEP view of the solid structure of compounds $\mathbf{6 c}$ and $\mathbf{6 d}$ with thermal ellipsoids set at $50 \%$ probability. Hydrogen atoms and solvent molecules have been excluded for the sake of clarity. Selected bond distances $(\AA)$ and angles $\left(^{\circ}\right)$ : Compound 6c: Ir1-P1, 2.295(6); Ir2-P2, 2.296(7); Ir3-P3, 2.302(8); Ir1-Cl2. 2.396(6); Ir1-Cl1. 2.420(6); Ir2-Cl3, 2.398(8); Ir2-Cl4, 2.398(8); Ir3-Cl6, 2.398(7); Ir3-Cl5, 2.406(6); P1-O1, 1.637(17); P2-O2, 1.65(2); P3-O3, 1.646(19); C1-C2, 1.62(3); P1-Ir1-Cl2, 92.6(2); P1-Ir-Cl1, 92.1(2); Cl2-Ir1-Cl1, 85.0(2); P2-Ir2-Cl3, 90.0(3); P2-Ir2-Cl4, 88.6(3); P3-Ir3-Cl6, 89.9(3); P3-Ir3-Cl5, 92.1(2). Compound 6d: Ir1-P1, 2.2801(14); Ir1-Cl1, 2.3940(17); Ir1-Cl2, 2.4003(16); Ir2-P2, 2.3088(14); Ir2-Cl4, 2.3896(17); Ir2-Cl3, 2.4066(16); Ir3-P3, 2.2862(15); Ir3-Cl5, 2.4000(14); Ir3-Cl6, 2.4146(16); P1-O1, 1.642(4); P2-O2, 1.645(4); P3-O3, 1.638(4); C1-C2, 1.562(7); P1-Ir1-Cl1, 92.05(6); C21-Ir1-Cl2, 98.65(18); P1-Ir1-Cl2, 92.07(5); Cl1-Ir1-Cl2, 86.82(7); P2-Ir2-Cl4, 91.22(5); P2-Ir2-Cl3, 87.27(5); P3-Ir3-Cl5, 90.89(5); P3-Ir3-Cl6, 89.09(6); Cl5-Ir3-Cl6, 89.02(7); O1-P1-Ir1, 112.94(15); O2-P2-Ir2, 115.71(14); O3-P3-Ir3, 113.42(17).

\section{Materials and Methods}

General considerations. All preparations and manipulations were carried out using standard Schlenk and glove-box techniques under an atmosphere of high purity nitrogen. All solvents were dried, stored over $4 \AA$ molecular sieves, and degassed prior to use. Dichloromethane $\left(\mathrm{CH}_{2} \mathrm{Cl}_{2}\right)$ was distilled under nitrogen over $\mathrm{CaH}_{2}$. Toluene $\left(\mathrm{C}_{7} \mathrm{H}_{8}\right)$ and $n$-pentane $\left(\mathrm{C}_{5} \mathrm{H}_{12}\right)$ were distilled under nitrogen over sodium. Tetrahydrofuran (THF) and diethyl ether were distilled under nitrogen over sodium/benzophenone. [ $\mathrm{D}_{6}$ ] Benzene was dried over sodium, while $\mathrm{CDCl}_{3}$ and $\mathrm{CD}_{2} \mathrm{Cl}_{2}$ over molecular sieves $(4 \AA)$ and distilled under nitrogen. $\mathrm{Et}_{3} \mathrm{~N}$ was dried over $\mathrm{KOH}$ and distilled over nitrogen. $[\mathrm{AuCl}(\mathrm{THT})]\left(\mathrm{THT}=\right.$ tetrahydrothiophene) [59], [( $\left.\left.\eta^{5}-\mathrm{C}_{5} \mathrm{Me}_{5}\right) \mathrm{RhCl}_{2}\right]_{2}$ and $\left[\left(\eta^{5}-\mathrm{C}_{5} \mathrm{Me}_{5}\right) \mathrm{IrCl}_{2}\right]_{2}[60]$, $\left[\left(\eta^{6}-\mathrm{C}_{10} \mathrm{H}_{14}\right) \mathrm{RuCl}_{2}\right]_{2}$ [61], and chlorodixylyl phosphine [57] were prepared as described previously. Other chemicals were commercially available and used as received. Solution NMR spectra were recorded on Bruker AMX-300, DRX-400, and DRX-500 spectrometers. Spectra were referenced to external $\mathrm{SiMe}_{4}(\delta: 0 \mathrm{ppm})$ using the residual proton solvent peaks as internal standards $\left({ }^{1} \mathrm{H} \mathrm{NMR}\right.$ experiments), or the characteristic resonances of the solvent nuclei $\left({ }^{13} \mathrm{C}\right.$ NMR experiments), while ${ }^{31} \mathrm{P}$ was referenced to $\mathrm{H}_{3} \mathrm{PO}_{4}$. Spectral assignments were made by routine one- and two-dimensional NMR experiments where appropriate (Figure 7). For elemental analyses, a LECO TruSpec CHN elementary analyzer was utilized. CCDC 1973685-1973691 contain the supplementary crystallographic data for this paper. These data can be obtained free of charge from The Cambridge Crystallographic Data Centre.

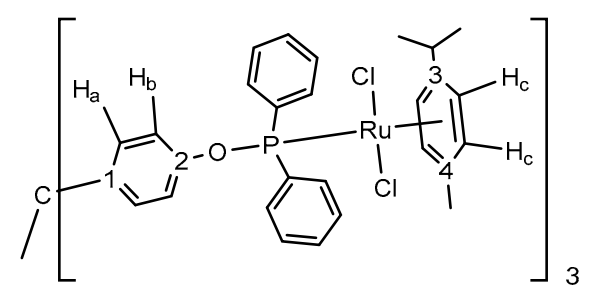

Figure 7. Labeling scheme used for ${ }^{1} \mathrm{H}$ and ${ }^{13} \mathrm{C}\left\{{ }^{1} \mathrm{H}\right\} \mathrm{NMR}$ assignments. 
Synthesis of trisphosphinites. Method A (ligands 1a and 1c). To a $\mathrm{Et}_{2} \mathrm{O}(5 \mathrm{~mL})$ solution of 1,1,1-tris(4-hydroxyphenyl)-ethane $\left(80.0 \mathrm{mg}, 0.26 \mathrm{mmol}\right.$ ) was added $\mathrm{Et}_{3} \mathrm{~N}(365 \mu \mathrm{L}, 2.63 \mathrm{mmol})$ at room temperature and under nitrogen atmosphere. Then, the corresponding chlorophosphine $\left(\mathrm{PClPh}_{2}: 170\right.$ $\mu \mathrm{L}, 0.92 \mathrm{mmol} ; \mathrm{PCl}^{i} \mathrm{Pr}_{2}: 145 \mu \mathrm{L}, 0.92 \mathrm{mmol}$ ) was added dropwise. The solution was stirred at room temperature overnight, after which it was filtrated and concentrated (to ca. $1 \mathrm{~mL}$ ) under vacuum. Compound 1a was isolated as a white solid $(189 \mathrm{mg}, 0.22 \mathrm{mmol}, 84 \%)$ by precipitation with pentane (5-10 $\mathrm{mL}$ ) and after filtering off and drying the solid under reduced pressure. Compound $\mathbf{1} \mathbf{c}$ was isolated as a colorless oil $\left(109 \mathrm{mg}, 0.17 \mathrm{mmol}, 64 \%\right.$ ) after evaporation of the $\mathrm{Et}_{2} \mathrm{O}$ solution and used without further purification. Method B. To a THF (5 mL) suspension of 1,1,1-tris(4-hydroxyphenyl)-ethane $(80.0 \mathrm{mg}, 0.26 \mathrm{mmol})$ and $\mathrm{NaH}(63.0 \mathrm{mg}, 2.63 \mathrm{mmol})$ in a J. Young ampoule at room temperature, a THF solution of the corresponding phosphine $\left(\mathrm{PCl}(\mathrm{Xyl})_{2}: 255 \mathrm{mg}, 0.92 \mathrm{mmol} ; \mathrm{PClCy}: 215 \mathrm{mg}\right.$, 0.92 $\mathrm{mmol}$ ) was added dropwise. The solution was stirred at room temperature for three days. For better yields, $\mathrm{Et}_{3} \mathrm{~N}(220 \mu \mathrm{L}, 1.58 \mathrm{mmol})$ was subsequently added to the reaction mixture, and the suspension further stirred overnight. The reaction mixture was filtrated and the solvents were evaporated under vacuum, yielding a colorless oil that was extracted with pentane. The resulting white sticky foam was used without further purification (1d: $148 \mathrm{mg}, 0.16 \mathrm{mmol}, 63 \%)$. Crystals of $\mathbf{1 b}$ suitable for X-ray diffraction studies were grown by slow evaporation of the reaction crude (13.2 $\mathrm{mg}, 0.01 \mathrm{mmol} 5 \%)$. These compounds were characterized by spectroscopic methods, except for $1 \mathrm{c}$ that also includes a single crystal X-ray diffraction analysis, and 1a for which elemental analysis is also provided. Compound 1a. Anal. Calc. for $\mathrm{C}_{56} \mathrm{H}_{45} \mathrm{O}_{3} \mathrm{P}_{3}: \mathrm{C}, 78.31 ; \mathrm{H}, 5.28$. Found: $\mathrm{C}, 78.33 ; \mathrm{H}, 5.57 .{ }^{1} \mathrm{H}$ NMR $\left(400 \mathrm{MHz}, \mathrm{CDCl}_{3}, 25\right.$ $\left.{ }^{\circ} \mathrm{C}\right) \delta: 7.60-7.53\left(\mathrm{~m}, 12 \mathrm{H}, o-\mathrm{C}_{6} \mathrm{H}_{5}\right), 7.42-7.35\left(\mathrm{~m}, 18 \mathrm{H}, m-\mathrm{C}_{6} \mathrm{H}_{5} ; p-\mathrm{C}_{6} \mathrm{H}_{5}\right), 6.98\left(\mathrm{dd}, 6 \mathrm{H},{ }^{3} J_{\mathrm{HH}}=8.8 \mathrm{~Hz}\right.$, $\left.{ }^{4} J_{\mathrm{H} \mathrm{P}}=1.2 \mathrm{~Hz}, \mathrm{H}_{\mathrm{b}}\right), 6.94\left(\mathrm{~d}, 6 \mathrm{H},{ }^{3} J_{\mathrm{HH}}=8.8 \mathrm{~Hz}, \mathrm{H}_{\mathrm{a}}\right), 2.05 \mathrm{ppm}\left(\mathrm{s}, 3 \mathrm{H}, \mathrm{CCH}_{3}\right) .{ }^{13} \mathrm{C}\left\{{ }^{1} \mathrm{H}\right\} \mathrm{NMR}(100 \mathrm{MHz}$, $\left.\mathrm{CDCl}_{3}, 25^{\circ} \mathrm{C}\right) \delta: 155.5\left(\mathrm{~d},{ }^{2} J_{\mathrm{CP}}=10 \mathrm{~Hz}, \mathrm{C}_{2}\right), 143.5\left(\mathrm{~s}, \mathrm{C}_{1}\right), 141.1\left(\mathrm{~d},{ }^{1} J_{\mathrm{CP}}=18 \mathrm{~Hz}\right.$, ipso- $\left.\mathrm{C}_{6} \mathrm{H}_{5}\right), 130.7$ $\left(\mathrm{d},{ }^{2} J_{\mathrm{CP}}=22 \mathrm{~Hz}, o-\mathrm{C}_{6} \mathrm{H}_{5}\right), 129.8\left(\mathrm{~s}, \mathrm{CH}_{\mathrm{a}} ; p-\mathrm{C}_{6} \mathrm{H}_{5}\right), 128.6\left(\mathrm{~d},{ }^{3} J_{\mathrm{CP}}=7 \mathrm{~Hz}, m-\mathrm{C}_{6} \mathrm{H}_{5}\right), 118.1\left(\mathrm{~d},{ }^{3} J_{\mathrm{CP}}=11\right.$ $\left.\mathrm{Hz}, \mathrm{CH}_{\mathrm{b}}\right), 51.1\left(\mathrm{~s}, \mathrm{CCH}_{3}\right), 30.5 \mathrm{ppm}\left(\mathrm{s}, \mathrm{CCH}_{3}\right) .{ }^{31} \mathrm{P}\left\{{ }^{1} \mathrm{H}\right\} \mathrm{NMR}\left(162 \mathrm{MHz}, \mathrm{CDCl}_{3}, 25^{\circ} \mathrm{C}\right) \delta: 110.5 \mathrm{ppm}$. Compound 1b. ${ }^{1} \mathrm{H} \mathrm{NMR}\left(400 \mathrm{MHz}, \mathrm{CDCl}_{3}, 25^{\circ} \mathrm{C}\right) \delta: 7.12\left(\mathrm{t}, 6 \mathrm{H},{ }^{3} \mathrm{~J}_{\mathrm{HH}}=7.5 \mathrm{~Hz}, p-\mathrm{C}_{6} \mathrm{H}_{5}\right), 6.99-6.93$ $\left(\mathrm{m}, 18 \mathrm{H}, m-\mathrm{C}_{6} \mathrm{H}_{5} ; \mathrm{H}_{\mathrm{b}}\right), 6.91\left(\mathrm{~d}, 6 \mathrm{H},{ }^{3} \mathrm{~J}_{\mathrm{HH}}=8.9 \mathrm{~Hz}, \mathrm{H}_{\mathrm{a}}\right), 2.37\left(\mathrm{~s}, 36 \mathrm{H}, \mathrm{CH}_{3}(\mathrm{Xyl})\right), 2.05\left(\mathrm{~s}, 3 \mathrm{H}, \mathrm{CCH}_{3}\right)$. ${ }^{13} \mathrm{C}\left\{{ }^{1} \mathrm{H}\right\} \mathrm{NMR}\left(100 \mathrm{MHz}, \mathrm{CDCl}_{3}, 25{ }^{\circ} \mathrm{C}\right) \delta: 155.1\left(\mathrm{~d},{ }^{2} \mathrm{~J}_{\mathrm{CP}}=14 \mathrm{~Hz}, \mathrm{C}_{2}\right), 143.0\left(\mathrm{~s}, \mathrm{C}_{1}\right), 141.6\left(\mathrm{~d},{ }^{2} \mathrm{~J}_{\mathrm{CP}}=\right.$ $17 \mathrm{~Hz}, o-\mathrm{Xyl}), 136.9\left(\mathrm{~d},{ }^{1} J_{\mathrm{CP}}=27 \mathrm{~Hz}, i p s o-X y l\right), 129.8\left(\mathrm{~s}, \mathrm{CH}_{\mathrm{a}}\right), 129.3\left(\mathrm{~d},{ }^{3} J_{\mathrm{CP}}=7 \mathrm{~Hz}, m-\mathrm{Xyl}\right), 129.3(\mathrm{~s}$, p-Xyl), $117.5\left(\mathrm{~d},{ }^{3} J_{\mathrm{CP}}=13 \mathrm{~Hz}, \mathrm{CH}_{\mathrm{b}}\right), 51.0\left(\mathrm{~s}, \mathrm{CCH}_{3}\right), 32.3\left(\mathrm{~s}, \mathrm{CCH}_{3}\right), 22.5\left(\mathrm{~d},{ }^{3} J_{\mathrm{CP}}=14 \mathrm{~Hz}, \mathrm{CH}_{3}(\mathrm{Xyl})\right)$. ${ }^{31} \mathrm{P}\left\{{ }^{1} \mathrm{H}\right\}$ NMR $\left(121 \mathrm{MHz}, \mathrm{CDCl}_{3}, 25^{\circ} \mathrm{C}\right) \delta: 113.5 \mathrm{ppm}$. Compound 1c. ${ }^{1} \mathrm{H}$ NMR $\left(300 \mathrm{MHz}, \mathrm{CDCl}_{3}, 25\right.$ $\left.{ }^{\circ} \mathrm{C}\right) \delta: 6.94\left(\mathrm{~m}, 12 \mathrm{H}, \mathrm{H}_{\mathrm{a}} ; \mathrm{H}_{\mathrm{b}}\right), 2.07\left(\mathrm{~s}, 3 \mathrm{H}, \mathrm{CCH}_{3}\right), 1.91\left(\mathrm{septd}, 6 \mathrm{H},{ }^{3} J_{\mathrm{HH}}=7.0 \mathrm{~Hz},{ }^{2} J_{\mathrm{HP}}=2.2 \mathrm{~Hz}, \mathrm{CH}\right.$ $\left.\left({ }^{\mathrm{i}} \mathrm{Pr}\right)\right), 1.17\left(\mathrm{dd}, 18 \mathrm{H},{ }^{3} J_{\mathrm{HH}}=7.0 \mathrm{~Hz},{ }^{3} J_{\mathrm{HP}}=10.7 \mathrm{~Hz}, \mathrm{CH}_{3}\left({ }^{\mathrm{i}} \mathrm{Pr}\right)\right), 1.09 \mathrm{ppm}\left(\mathrm{dd}, 18 \mathrm{H},{ }^{3} J_{\mathrm{HH}}=7.2 \mathrm{~Hz},{ }^{3} J_{\mathrm{HP}}\right.$ $\left.=15.9 \mathrm{~Hz}, \mathrm{CH}_{3}\left({ }^{\mathrm{i} P r}\right)\right) .{ }^{13} \mathrm{C}\left\{{ }^{1} \mathrm{H}\right\} \mathrm{NMR}\left(75 \mathrm{MHz}, \mathrm{CDCl}_{3}, 25^{\circ} \mathrm{C}\right) \delta: 157.6\left(\mathrm{~d},{ }^{2} J_{\mathrm{CP}}=9 \mathrm{~Hz}, \mathrm{C}_{2}\right), 143.1(\mathrm{~s}$, $\left.\mathrm{C}_{1}\right), 129.9\left(\mathrm{~s}, \mathrm{CH}_{\mathrm{a}}\right) 118.1\left(\mathrm{~d},{ }^{3} J_{\mathrm{CP}}=10 \mathrm{~Hz}, \mathrm{CH}_{\mathrm{b}}\right), 51.1\left(\mathrm{~s}, \mathrm{CCH}_{3}\right), 31.2\left(\mathrm{~s}, \mathrm{CCH}_{3}\right), 28.7\left(\mathrm{~d},{ }^{1} J_{\mathrm{CP}}=17 \mathrm{~Hz}\right.$, $\left.\mathrm{CH}\left({ }^{\mathrm{i}} \mathrm{Pr}\right)\right), 18.2\left(\mathrm{~d},{ }^{2} J_{\mathrm{CP}}=20 \mathrm{~Hz}, \mathrm{CH}_{3}\left({ }^{\mathrm{i}} \mathrm{Pr}\right)\right), 17.4 \mathrm{ppm}\left(\mathrm{d},{ }^{2} J_{\mathrm{CP}}=8 \mathrm{~Hz}, \mathrm{CH}_{3}\left({ }^{\mathrm{i}} \mathrm{Pr}\right)\right) .{ }^{31} \mathrm{P}\left\{{ }^{1} \mathrm{H}\right\} \mathrm{NMR}(121$ $\left.\mathrm{MHz}, \mathrm{CDCl}_{3}, 25^{\circ} \mathrm{C}\right) \delta: 149.4 \mathrm{ppm}$. Compound 1d. ${ }^{1} \mathrm{H}$ NMR $\left(400 \mathrm{MHz}, \mathrm{CD}_{2} \mathrm{Cl}_{2}, 25^{\circ} \mathrm{C}\right)$ 8: $7.00(\mathrm{~m}, 12$ $\left.\mathrm{H}, \mathrm{H}_{\mathrm{a}} ; \mathrm{H}_{\mathrm{b}}\right), 2.11\left(\mathrm{~s}, 3 \mathrm{H}, \mathrm{CCH}_{3}\right), 2.00-1.27 \mathrm{ppm}\left(\mathrm{m}, 66 \mathrm{H}, \mathrm{CH}(\mathrm{Cy}) ; \mathrm{CH}_{2}(\mathrm{Cy})\right) .{ }^{13} \mathrm{C}\left\{{ }^{1} \mathrm{H}\right\} \mathrm{NMR}(100 \mathrm{MHz}$, $\left.\mathrm{CD}_{2} \mathrm{Cl}_{2}, 25^{\circ} \mathrm{C}\right) \delta: 158.4\left(\mathrm{~d},{ }^{2} J_{\mathrm{CP}}=9 \mathrm{~Hz}, \mathrm{C}_{2}\right), 143.4\left(\mathrm{~s}, \mathrm{C}_{1}\right), 130.2\left(\mathrm{~s}, \mathrm{CH}_{\mathrm{a}}\right), 118.5\left(\mathrm{~d},{ }^{3} J_{\mathrm{CP}}=10 \mathrm{~Hz}, \mathrm{CH}_{\mathrm{b}}\right)$, $51.6\left(\mathrm{~s}, \mathrm{CCH}_{3}\right), 38.9\left(\mathrm{~d},{ }^{1} J_{\mathrm{CP}}=18 \mathrm{~Hz}, \mathrm{CH}_{2}(\mathrm{Cy})\right), 31.5\left(\mathrm{~s}, \mathrm{CCH}_{3}\right), 28.9\left(\mathrm{~d},{ }^{2} \mathrm{~J}_{\mathrm{CP}}=19 \mathrm{~Hz}, \mathrm{CH}_{2}(\mathrm{Cy})\right), 27.8(\mathrm{~s}$, $\left.\mathrm{CH}_{2}(\mathrm{Cy})\right), 27.7\left(\mathrm{~d},{ }^{3} \mathrm{~J}_{\mathrm{CP}}=6 \mathrm{~Hz}, \mathrm{CH}_{2}(\mathrm{Cy})\right), 27.6\left(\mathrm{~s}, \mathrm{CH}_{2}(\mathrm{Cy})\right), 27.3 \mathrm{ppm}\left(\mathrm{s}, \mathrm{CH}_{2}(\mathrm{Cy})\right) .{ }^{31} \mathrm{P}\left\{{ }^{1} \mathrm{H}\right\} \mathrm{NMR}$ $\left(162 \mathrm{MHz}, \mathrm{CDCl}_{3}, 25^{\circ} \mathrm{C}\right) \delta: 144.6 \mathrm{ppm}$.

Compound 2a. A dichloromethane $(5 \mathrm{~mL})$ solution of $1 \mathrm{a}(334 \mathrm{mg}, 0.39 \mathrm{mmol})$ was slowly added at $0{ }^{\circ} \mathrm{C}$ and under nitrogen atmosphere over a dichloromethane $(5 \mathrm{~mL})$ solution of [AuCl(THT)] (374 $\mathrm{mg}, 1.17 \mathrm{mmol}$ ). The solution was stirred at $0{ }^{\circ} \mathrm{C}$ for $5 \mathrm{~h}$, then the solvent was concentrated under vacuum, and pentane addition caused the precipitation of a white solid, which was further washed with pentane for several times yielding compound $2 \mathrm{a}$ as a white solid (580 $\mathrm{mg}, 0.37 \mathrm{mmol}, 95 \%)$. Single crystals were obtained by slow diffusion of pentane into a benzene solution (3:1). Anal. Calc. for $\mathrm{C}_{56} \mathrm{H}_{45} \mathrm{Cl}_{3} \mathrm{O}_{3} \mathrm{P}_{3} \mathrm{Au}_{3}: \mathrm{C}, 43.22 ; \mathrm{H}, 2.91$. Found: $\mathrm{C}, 43.45 ; \mathrm{H}, 3.25 .{ }^{1} \mathrm{H} \mathrm{NMR}\left(400 \mathrm{MHz}, \mathrm{CD}_{2} \mathrm{Cl}_{2}, 25^{\circ} \mathrm{C}\right) \delta$ : $7.92-7.82\left(\mathrm{~m}, 12 \mathrm{H}, o-\mathrm{C}_{6} \mathrm{H}_{5}\right), 7.67-753\left(\mathrm{~m}, 18 \mathrm{H}, m-\mathrm{C}_{6} \mathrm{H}_{5} ; p-\mathrm{C}_{6} \mathrm{H}_{5}\right), 7.05\left(\mathrm{dd}, 6 \mathrm{H},{ }^{3} J_{\mathrm{HH}}=8.9 \mathrm{~Hz},{ }^{4} J_{\mathrm{HP}}=\right.$ 
$\left.\left.1.2 \mathrm{~Hz}, \mathrm{H}_{\mathrm{b}}\right), 6.96\left(\mathrm{~d}, 6 \mathrm{H},{ }^{3} J_{\mathrm{HH}}=8.9 \mathrm{~Hz}, \mathrm{H}_{\mathrm{b}}\right), 2.12 \mathrm{ppm}\left(\mathrm{s}, 3 \mathrm{H}, \mathrm{CCH}_{3}\right) .{ }^{13} \mathrm{C}^{1} \mathrm{H}\right\} \mathrm{NMR}\left(100 \mathrm{MHz}, \mathrm{CD}_{2} \mathrm{Cl}_{2}\right.$, $\left.25^{\circ} \mathrm{C}\right) \delta: 153.2\left(\mathrm{~d},{ }^{2} J_{\mathrm{CP}}=5 \mathrm{~Hz}, \mathrm{C}_{2}\right), 146.3\left(\mathrm{~s}, \mathrm{C}_{1}\right), 133.8\left(\mathrm{~s}, p-\mathrm{C}_{6} \mathrm{H}_{5}\right), 133.3\left(\mathrm{~d},{ }^{1} J_{\mathrm{CP}}=70 \mathrm{~Hz}, i p s o-\mathrm{C}_{6} \mathrm{H}_{5}\right)$, $133.0\left(\mathrm{~d},{ }^{2} J_{\mathrm{CP}}=16 \mathrm{~Hz}, o-\mathrm{C}_{6} \mathrm{H}_{5}\right), 131.0\left(\mathrm{~s}, \mathrm{CH}_{\mathrm{a}}\right), 130.0\left(\mathrm{~d},{ }^{3} J_{\mathrm{CP}}=12 \mathrm{~Hz}, m-\mathrm{C}_{6} \mathrm{H}_{5}\right), 120.5\left(\mathrm{~d},{ }^{3} J_{\mathrm{CP}}=7 \mathrm{~Hz}\right.$, $\left.\mathrm{CH}_{\mathrm{b}}\right), 52.2\left(\mathrm{~s}, \mathrm{CCH}_{3}\right), 30.9 \mathrm{ppm}\left(\mathrm{s}, \mathrm{CCH}_{3}\right) .{ }^{31} \mathrm{P}\left\{{ }^{1} \mathrm{H}\right\} \mathrm{NMR}\left(162 \mathrm{MHz}, \mathrm{CD}_{2} \mathrm{Cl}_{2}, 25^{\circ} \mathrm{C}\right) \delta: 112.8 \mathrm{ppm}$.

Compound 2b. To a toluene solution (1-2 mL) of [AuTHTCl] (12.4 mg, $0.04 \mathrm{mmol}$ ) in a Schlenk flask was added dropwise a toluene solution $(1-2 \mathrm{~mL})$ of $\mathbf{1 b}(13.3 \mathrm{mg}, 0.01 \mathrm{mmol})$ at $0{ }^{\circ} \mathrm{C}$. The resulting solution was stirred for $1 \mathrm{~h}$, then the solvent was concentrated up to the minimum volume and precipitated with pentane, washed with pentane $(2 \times 3 \mathrm{~mL})$ yielding a pure white solid $(7.000 \mathrm{mg}, 31 \%$ yield). Anal. Calc. for $\mathrm{C}_{68} \mathrm{H}_{69} \mathrm{Cl}_{3} \mathrm{O}_{3} \mathrm{P}_{3} \mathrm{Au}_{3}: \mathrm{C}, 47.36 ; \mathrm{H}, 4.03$. Found: $\mathrm{C}, 46.94 ; \mathrm{H}, 3.98 .{ }^{1} \mathrm{H}$ NMR (400 $\left.\mathrm{MHz}, \mathrm{CD}_{2} \mathrm{Cl}_{2}, 25^{\circ} \mathrm{C}\right) \delta: 7.34\left(\mathrm{t}, 6 \mathrm{H},{ }^{3} \mathrm{~J}_{\mathrm{HH}}=7.5 \mathrm{~Hz}, p-\mathrm{C}_{6} \mathrm{H}_{5}\right), 7.17-7.05\left(\mathrm{~m}, 12 \mathrm{H}, m-\mathrm{C}_{6} \mathrm{H}_{5}\right), 6.95(\mathrm{~d}, 6 \mathrm{H}$, $\left.{ }^{3} J_{\mathrm{HH}}=8.7 \mathrm{~Hz}, \mathrm{H}_{\mathrm{b}}\right), 6.90\left(\mathrm{~d}, 6 \mathrm{H},{ }^{3} J_{\mathrm{HH}}=8.7 \mathrm{~Hz}, \mathrm{H}_{\mathrm{a}}\right), 2.56\left(\mathrm{~s}, 36 \mathrm{H}, \mathrm{CH}_{3}(\mathrm{Xyl})\right), 2.07 \mathrm{ppm}\left(\mathrm{s}, 3 \mathrm{H}, \mathrm{CCH}_{3}\right)$. ${ }^{13} \mathrm{C}\left\{{ }^{1} \mathrm{H}\right\} \mathrm{NMR}\left(100 \mathrm{MHz}, \mathrm{CD}_{2} \mathrm{Cl}_{2}, 25{ }^{\circ} \mathrm{C}\right) \delta: 152.9\left(\mathrm{~d},{ }^{2} J_{\mathrm{CP}}=5 \mathrm{~Hz}, \mathrm{C}_{2}\right), 146.0\left(\mathrm{~s}, \mathrm{C}_{1}\right), 142.3\left(\mathrm{~d},{ }^{2} J_{\mathrm{CP}}=\right.$ $12 \mathrm{~Hz}, o-X y l), 132.9$ (s, p-Xyl), $131.7\left(\mathrm{~d},{ }^{3} J_{\mathrm{CP}}=9 \mathrm{~Hz}, m-\mathrm{Xyl}\right), 131.0\left(\mathrm{~d},{ }^{1} J_{\mathrm{CP}}=64 \mathrm{~Hz}, i p s o-X y l\right), 130.9$ (s, $\left.\mathrm{CH}_{\mathrm{a}}\right), 120.2\left(\mathrm{~d},{ }^{3} J_{\mathrm{CP}}=7 \mathrm{~Hz}, \mathrm{CH}_{\mathrm{b}}\right), 52.1\left(\mathrm{~s}, \mathrm{CCH}_{3}\right), 30.9\left(\mathrm{~s}, \mathrm{CCH}_{3}\right), 24.5 \mathrm{ppm}\left(\mathrm{d},{ }^{3} J_{\mathrm{CP}}=9 \mathrm{~Hz}, \mathrm{CH}_{3}(\mathrm{Xyl})\right)$. ${ }^{31} \mathrm{P}\left\{{ }^{1} \mathrm{H}\right\} \mathrm{NMR}\left(202 \mathrm{MHz}, \mathrm{CD}_{2} \mathrm{Cl}_{2}, 25^{\circ} \mathrm{C}\right) \delta: 103.6 \mathrm{ppm}$.

Compound 3a. To a $\mathrm{CH}_{2} \mathrm{Cl}_{2}$ solution ( $\left.2-3 \mathrm{~mL}\right)$ of [AgOTf] $\left(\mathrm{OTf}^{-}=\mathrm{OSO}_{2} \mathrm{CF}_{3}{ }^{-}\right)(43.4 \mathrm{mg}, 0.17$ $\mathrm{mmol})$ in a Schlenk flask was slowly added a $\mathrm{CH}_{2} \mathrm{Cl}_{2}$ solution $(\sim 2-3 \mathrm{~mL})$ of $\mathbf{1}(50.0 \mathrm{mg}, 0.06 \mathrm{mmol})$ at room temperature in the absence of light. The resulting solution was stirred for $3-4 \mathrm{~h}$. After this, the solvent was concentrated up to the minimum volume and precipitated with pentane, washed with pentane $(2 \times 5 \mathrm{~mL})$ and diethyl ether $(1 \times 3 \mathrm{~mL})$ yielding a pure white solid $(68.0 \mathrm{mg}, 0.04 \mathrm{mmol}, 72 \%$ yield) that remain stable under air for several hours. Anal. Calc. for $\mathrm{C}_{59} \mathrm{H}_{45} \mathrm{~F}_{9} \mathrm{O}_{12} \mathrm{P}_{3} \mathrm{~S}_{3} \mathrm{Ag}_{3}: \mathrm{C}, 43.48 ; \mathrm{H}$, 2.78; S, 5.90. Found: $\mathrm{C}, 43.28 ; \mathrm{H}, 3.12 ; \mathrm{S}, 5.70 .{ }^{1} \mathrm{H}$ NMR $\left(400 \mathrm{MHz}, \mathrm{CD}_{2} \mathrm{Cl}_{2}, 25^{\circ} \mathrm{C}\right) \delta: 7.80-7.68(\mathrm{~m}, 12 \mathrm{H}$, $\left.o-\mathrm{C}_{6} \mathrm{H}_{5}\right), 7.60-7.45\left(\mathrm{~m}, 18 \mathrm{H}, m-\mathrm{C}_{6} \mathrm{H}_{5} ; p-\mathrm{C}_{6} \mathrm{H}_{5}\right), 7.03\left(\mathrm{~d}, 6 \mathrm{H},{ }^{3} J_{\mathrm{HH}}=8.6 \mathrm{~Hz}, \mathrm{H}_{\mathrm{a}}\right), 6.97\left(\mathrm{~d}, 6 \mathrm{H},{ }^{3} J_{\mathrm{HH}}=\right.$ $\left.8.3 \mathrm{~Hz}, \mathrm{H}_{\mathrm{b}}\right), 2.05 \mathrm{ppm}\left(\mathrm{s}, 3 \mathrm{H}, \mathrm{CCH}_{3}\right) .{ }^{13} \mathrm{C}\left\{{ }^{1} \mathrm{H}\right\} \mathrm{NMR}\left(100 \mathrm{MHz}, \mathrm{CD}_{2} \mathrm{Cl}_{2}, 25^{\circ} \mathrm{C}\right) \delta: 155.1\left(\mathrm{~s}, \mathrm{C}_{2}\right), 146.3$ $\left(\mathrm{s}, \mathrm{C}_{1}\right), 134.4\left(\mathrm{~d},{ }^{1} J_{\mathrm{CP}}=38 \mathrm{~Hz}, i p s o-\mathrm{C}_{6} \mathrm{H}_{5}\right), 133.2\left(\mathrm{~s}, p-\mathrm{C}_{6} \mathrm{H}_{5}\right), 132.3\left(\mathrm{~d},{ }^{2} \mathrm{~J}_{\mathrm{CP}}=19 \mathrm{~Hz}, o-\mathrm{C}_{6} \mathrm{H}_{5}\right), 131.2(\mathrm{~s}$, $\left.\mathrm{CH}_{\mathrm{a}}\right), 130.0\left(\mathrm{~d},{ }^{3} J_{\mathrm{CP}}=11 \mathrm{~Hz}, m-\mathrm{C}_{6} \mathrm{H}_{5}\right), 119.9\left(\mathrm{~d},{ }^{3} J_{\mathrm{CP}}=9 \mathrm{~Hz}, \mathrm{CH}_{\mathrm{b}}\right), 52.1\left(\mathrm{~s}, \mathrm{CCH}_{3}\right), 30.7 \mathrm{ppm}\left(\mathrm{s}, \mathrm{CCH}_{3}\right)$. ${ }^{19} \mathrm{~F}\left\{{ }^{1} \mathrm{H}\right\}$ NMR (376 MHz, $\left.\mathrm{CD}_{2} \mathrm{Cl}_{2}, 25{ }^{\circ} \mathrm{C}\right) \delta:-77.4 \mathrm{ppm} .{ }^{31} \mathrm{P}\left\{{ }^{1} \mathrm{H}\right\} \mathrm{NMR}\left(202 \mathrm{MHz}, \mathrm{CD}_{2} \mathrm{Cl}_{2}, 25{ }^{\circ} \mathrm{C}\right) \delta$ : $120.6 \mathrm{ppm}$.

Compound 4a. To a $\mathrm{CH}_{2} \mathrm{Cl}_{2}$ solution $(7-8 \mathrm{~mL})$ of $\mathrm{CuCl}(30.0 \mathrm{mg}, 0.30 \mathrm{mmol})$ in a Schlenk flask was added dropwise a $\mathrm{CH}_{2} \mathrm{Cl}_{2}$ solution ( $\left.3-4 \mathrm{~mL}\right)$ of $1(89.1 \mathrm{mg}, 0.10 \mathrm{mmol}$ ) at room temperature. The resulting solution was left stirred overnight $(\sim 14 \mathrm{~h})$. After this, upon concentration, the solution turns into a white residue that was washed with pentane, diethyl ether and toluene, yielding a pure white solid ( $97.1 \mathrm{mg}, 0.08 \mathrm{mmol}, 81 \%$ yield) that remain stable under air for several hours. Anal. Calc. for $\mathrm{C}_{56} \mathrm{H}_{45} \mathrm{Cl}_{3} \mathrm{O}_{3} \mathrm{P}_{3} \mathrm{Cu}_{3}: \mathrm{C}, 58.19 ; \mathrm{H}, 3.92$. Found: $\mathrm{C}, 57.86 ; \mathrm{H}, 4.14 .{ }^{1} \mathrm{H} \mathrm{NMR}\left(400 \mathrm{MHz}, \mathrm{CDCl}_{3}, 2{ }^{\circ} \mathrm{C}\right) \delta$ : 7.77-7.55 (m, $\left.12 \mathrm{H}, o-\mathrm{C}_{6} \mathrm{H}_{5}\right), 7.37-7.18\left(\mathrm{~m}, 18 \mathrm{H}, m-\mathrm{C}_{6} \mathrm{H}_{5} ; p-\mathrm{C}_{6} \mathrm{H}_{5}\right), 6.71-6.56\left(\mathrm{~m}, 6 \mathrm{H}, \mathrm{H}_{\mathrm{b}}\right), 6.56-6.38(\mathrm{~m}$, $\left.6 \mathrm{H}, \mathrm{H}_{\mathrm{a}}\right), 1.76 \mathrm{ppm}\left(\mathrm{s}, 3 \mathrm{H}, \mathrm{CCH}_{3}\right) .{ }^{13} \mathrm{C}\left\{{ }^{1} \mathrm{H}\right\} \mathrm{NMR}\left(100 \mathrm{MHz}, \mathrm{CDCl}_{3}, 25^{\circ} \mathrm{C}\right) \delta: 153.0\left(\mathrm{~s}, \mathrm{C}_{2}\right), 143.8\left(\mathrm{~s}, \mathrm{C}_{1}\right)$, $131.4\left(\mathrm{~s},{ }^{2} J_{\mathrm{CP}}=9 \mathrm{~Hz}, o-\mathrm{C}_{6} \mathrm{H}_{5}\right), 130.9\left(\mathrm{~s}, p-\mathrm{C}_{6} \mathrm{H}_{5}\right), 129.8\left(\mathrm{~s}, \mathrm{CH}_{\mathrm{a}}\right), 128.8\left(\mathrm{~s},{ }^{1} J_{\mathrm{CP}}=81 \mathrm{~Hz}, i p s o-\mathrm{C}_{6} \mathrm{H}_{5}\right), 128.7$ $\left(\mathrm{s}, m-\mathrm{C}_{6} \mathrm{H}_{5}\right), 118.6\left(\mathrm{~s}, \mathrm{CH}_{\mathrm{b}}\right), 50.8\left(\mathrm{~s}, \mathrm{CCH}_{3}\right), 30.5 \mathrm{ppm}\left(\mathrm{s}, \mathrm{CCH}_{3}\right) .{ }^{31} \mathrm{P}\left\{{ }^{1} \mathrm{H}\right\} \mathrm{NMR}\left(162 \mathrm{MHz}, \mathrm{CDCl}_{3}, 25^{\circ} \mathrm{C}\right)$ 8: $96.1 \mathrm{ppm}$ (br s).

General synthesis of group 9 compounds. A dichloromethane $(5 \mathrm{~mL})$ solution of a trisphosphinite ligand 1a (92.7 mg, $0.11 \mathrm{mmol} ; 68.7 \mathrm{mg}, 0.08 \mathrm{mmol}), 1 \mathrm{c}(81.5 \mathrm{mg}, 0.12 \mathrm{mmol})$, or $1 \mathrm{~d}(63.5 \mathrm{mg}, 0.07$ $\mathrm{mmol}$ ) were added at room temperature and under nitrogen atmosphere over a dichloromethane (5 $\mathrm{mL})$ solution of the corresponding transition metal precursor $\left(\left[\left(\eta^{5}-\mathrm{C}_{5} \mathrm{Me}_{5}\right) \mathrm{RhCl}_{2}\right]_{2}: 164.0 \mathrm{mg}, 0.092\right.$ mmol for $5 \mathbf{a} ;\left[\left(\eta^{5}-\mathrm{C}_{5} \mathrm{Me}_{5}\right) \mathrm{IrCl}_{2}\right]_{2}: 92.1 \mathrm{mg}, 0.23 \mathrm{mmol}$ for $\mathbf{6 a} ; 139 \mathrm{mg}, 0.17 \mathrm{mmol}$ for $6 \mathbf{c} ; 84.8 \mathrm{mg}, 0.11$ mmol for $\mathbf{6 d}$ ). The resulting solution was stirred for one hour, and then the solvent was concentrated at reduced pressure. A red solid for $\mathbf{5 a}$ or a yellow-orange for $\mathbf{6} \mathbf{a}$ were precipitated after addition of pentane, and it was subsequently washed with pentane or diethyl ether for several times yielding the corresponding trimetallic compounds (5a: $164 \mathrm{mg}, 0.09 \mathrm{mmol} 84 \%$; 6a: $130 \mathrm{mg}, 0.06 \mathrm{mmol}$ 83\%; 6c: $192 \mathrm{mg}$, $0.10 \mathrm{mmol}, 84 \%$; 6d: $130 \mathrm{mg}, 0.06 \mathrm{mmol}, 87 \%)$. Single crystals were obtained by either slow diffusion of diethyl ether into a dichloromethane solution (3:1) of the compound at $25^{\circ} \mathrm{C}(5 \mathbf{a}, \mathbf{6 a}, \mathbf{6 c})$ 
or by slow evaporation of a toluene solution of the compound (6d). Compound 5a. Anal. Calc. for $\mathrm{C}_{86} \mathrm{H}_{90} \mathrm{Cl}_{6} \mathrm{O}_{3} \mathrm{P}_{3} \mathrm{Rh}_{3}: \mathrm{C}, 57.84 ; \mathrm{H}, 5.08$. Found: $\mathrm{C}, 57.93 ; \mathrm{H}, 5.46 .{ }^{1} \mathrm{H}$ NMR $\left(400 \mathrm{MHz}, \mathrm{CD}_{2} \mathrm{Cl}_{2}, 25{ }^{\circ} \mathrm{C}\right) \delta$ : $8.15\left(\mathrm{~m}, 12 \mathrm{H}, o-\mathrm{C}_{6} \mathrm{H}_{5}\right), 7.42-7.32\left(\mathrm{~m}, 18 \mathrm{H}, m-\mathrm{C}_{6} \mathrm{H}_{5} ; p-\mathrm{C}_{6} \mathrm{H}_{5}\right), 7.28\left(\mathrm{~d}, 6 \mathrm{H},{ }^{3} J_{\mathrm{HH}}=8.7 \mathrm{~Hz}, \mathrm{H}_{\mathrm{b}}\right), 6.75(\mathrm{~d}, 6$ $\left.\mathrm{H},{ }^{3} J_{\mathrm{HH}}=8.8 \mathrm{~Hz}, \mathrm{H}_{\mathrm{a}}\right), 1.97\left(\mathrm{~s}, 3 \mathrm{H}, \mathrm{CCH}_{3}\right), 1.31 \mathrm{ppm}\left(\mathrm{d}, 45 \mathrm{H},{ }^{4} J_{\mathrm{HP}}=3.7 \mathrm{~Hz}, \mathrm{C}_{5} \mathrm{Me}_{5}\right) .{ }^{13} \mathrm{C}\left\{{ }^{1} \mathrm{H}\right\} \mathrm{NMR}$ $\left(100 \mathrm{MHz}, \mathrm{CD}_{2} \mathrm{Cl}_{2}, 25^{\circ} \mathrm{C}\right) \delta: 151.2\left(\mathrm{~d},{ }^{2} J_{\mathrm{CP}}=6 \mathrm{~Hz}, \mathrm{C}_{2}\right), 144.8\left(\mathrm{~s}, \mathrm{C}_{1}\right), 136.0\left(\mathrm{~d},{ }^{1} J_{\mathrm{CP}}=47 \mathrm{~Hz}\right.$, ipso- $\left.\mathrm{C}_{6} \mathrm{H}_{5}\right)$, $133.3\left(\mathrm{~d},{ }^{2} J_{\mathrm{CP}}=12 \mathrm{~Hz}, o-\mathrm{C}_{6} \mathrm{H}_{5}\right), 131.9\left(\mathrm{~s}, p-\mathrm{C}_{6} \mathrm{H}_{5}\right), 130.3\left(\mathrm{~s}, \mathrm{CH}_{\mathrm{a}}\right), 128.7\left(\mathrm{~d},{ }^{3} J_{\mathrm{CP}}=10 \mathrm{~Hz}, m-\mathrm{C}_{6} \mathrm{H}_{5}\right)$, $120.4\left(\mathrm{~d},{ }^{3} J_{\mathrm{CP}}=6 \mathrm{~Hz}, \mathrm{CH}_{\mathrm{b}}\right), 101.8\left(\mathrm{~d},{ }^{2} J_{\mathrm{CP}}=4 \mathrm{~Hz}, \mathrm{C}_{5} \mathrm{Me}_{5}\right), 51.6\left(\mathrm{~s}, \mathrm{CCH}_{3}\right), 30.9\left(\mathrm{~s}, \mathrm{CCH}_{3}\right), 9.4 \mathrm{ppm}(\mathrm{s}$, $\left.\mathrm{C}_{5} \mathrm{Me}_{5}\right) .{ }^{31} \mathrm{P}\left\{{ }^{1} \mathrm{H}\right\} \mathrm{NMR}\left(121 \mathrm{MHz}, \mathrm{CD}_{2} \mathrm{Cl}_{2}, 25^{\circ} \mathrm{C}\right) \delta: 113.7 \mathrm{ppm}\left(\mathrm{d},{ }^{1} J_{\mathrm{PRh}}=170 \mathrm{~Hz}\right)$. Compound $6 \mathbf{a}$. Anal. Calc. for $\mathrm{C}_{86} \mathrm{H}_{90} \mathrm{Cl}_{6} \mathrm{O}_{3} \mathrm{P}_{3} \mathrm{Ir}_{3}: \mathrm{C}, 50.29 ; \mathrm{H}, 4.42$. Found: $\mathrm{C}, 50.23 ; \mathrm{H}, 4.66$. MS (ESI) $m / z$ Calc. for $[\mathrm{M}$ $+\mathrm{H}-\mathrm{Cl}]^{+}$:_2041.3. Expt.: 2041.1. ${ }^{1} \mathrm{H}$ NMR $\left(400 \mathrm{MHz}, \mathrm{CD}_{2} \mathrm{Cl}_{2}, 25^{\circ} \mathrm{C}\right) \delta: 8.21-8.10\left(\mathrm{~m}, 12 \mathrm{H}, o-\mathrm{C}_{6} \mathrm{H}_{5}\right)$, 7.43-7.312(m, $\left.18 \mathrm{H}, m-\mathrm{C}_{6} \mathrm{H}_{5} ; p-\mathrm{C}_{6} \mathrm{H}_{5}\right), 7.25\left(\mathrm{~d}, 6 \mathrm{H},{ }^{3} J_{\mathrm{HH}}=8.8 \mathrm{~Hz}, \mathrm{H}_{\mathrm{b}}\right), 6.79\left(\mathrm{~d}, 6 \mathrm{H},{ }^{3} J_{\mathrm{HH}}=8.9 \mathrm{~Hz}, \mathrm{H}_{\mathrm{a}}\right)$, $1.99\left(\mathrm{~s}, 3 \mathrm{H}, \mathrm{CCH}_{3}\right), 1.30 \mathrm{ppm}\left(\mathrm{d}, 45 \mathrm{H},{ }^{4} \mathrm{~J}_{\mathrm{HP}}=2.2 \mathrm{~Hz}, \mathrm{C}_{5} \mathrm{Me}_{5}\right) \cdot{ }^{13} \mathrm{C}\left\{{ }^{1} \mathrm{H}\right\} \mathrm{NMR}\left(100 \mathrm{MHz}, \mathrm{CD}_{2} \mathrm{Cl}_{2}, 25^{\circ} \mathrm{C}\right)$ $\delta: 151.0\left(\mathrm{~d},{ }^{2} J_{\mathrm{CP}}=6 \mathrm{~Hz}, \mathrm{C}_{2}\right), 144.6\left(\mathrm{~s}, \mathrm{C}_{1}\right), 137.4\left(\mathrm{~d},{ }^{1} J_{\mathrm{CP}}=60 \mathrm{~Hz}\right.$, ipso- $\left.\mathrm{C}_{6} \mathrm{H}_{5}\right), 133.0\left(\mathrm{~d},{ }^{2} J_{\mathrm{CP}}=12 \mathrm{~Hz}\right.$, $\left.o-\mathrm{C}_{6} \mathrm{H}_{5}\right), 131.7\left(\mathrm{~s}, p-\mathrm{C}_{6} \mathrm{H}_{5}\right), 130.3\left(\mathrm{~s}, \mathrm{CH}_{\mathrm{a}}\right), 128.6\left(\mathrm{~d},{ }^{3} J_{\mathrm{CP}}=11 \mathrm{~Hz}, m-\mathrm{C}_{6} \mathrm{H}_{5}\right), 120.0\left(\mathrm{~d},{ }^{3} J_{\mathrm{CP}}=6 \mathrm{~Hz}, \mathrm{CH}_{\mathrm{b}}\right)$, $95.9\left(\mathrm{~s}, \mathrm{C}_{5} \mathrm{Me}_{5}\right), 51.6\left(\mathrm{~s}, \mathrm{CCH}_{3}\right), 31.0\left(\mathrm{~s}, \mathrm{CCH}_{3}\right), 8.9 \mathrm{ppm}\left(\mathrm{s}, \mathrm{C}_{5} \mathrm{Me}_{5}\right) .{ }^{31} \mathrm{P}\left\{{ }^{1} \mathrm{H}\right\} \mathrm{NMR}\left(121 \mathrm{MHz}, \mathrm{CD}_{2} \mathrm{Cl}_{2}\right.$, $25^{\circ} \mathrm{C}$ ) 8: 72.3. ppm. Compound 6c. Anal. Calc. for $\mathrm{C}_{68} \mathrm{H}_{102} \mathrm{Cl}_{6} \mathrm{O}_{3} \mathrm{P}_{3} \mathrm{Ir}_{3}: \mathrm{C}, 44.15 ; \mathrm{H}, 5.56$. Found: $\mathrm{C}$, 44.39; $\mathrm{H}, 5.61 .{ }^{1} \mathrm{H} \mathrm{NMR}\left(400 \mathrm{MHz}, \mathrm{CD}_{2} \mathrm{Cl}_{2}, 25^{\circ} \mathrm{C}\right) \delta: 7.26\left(\mathrm{~d}, 6 \mathrm{H},{ }^{3} J_{\mathrm{HH}}=8.8 \mathrm{~Hz}, \mathrm{H}_{\mathrm{b}}\right), 6.98\left(\mathrm{~d}, 6 \mathrm{H},{ }^{3} J_{\mathrm{HH}}\right.$ $\left.=8.6 \mathrm{~Hz}, \mathrm{H}_{\mathrm{a}}\right), 3.36-3.21\left(\mathrm{~m}, 6 \mathrm{H}, \mathrm{CH}\left({ }^{\mathrm{i}} \mathrm{Pr}\right)\right), 2.12\left(\mathrm{~s}, 3 \mathrm{H}, \mathrm{CCH}_{3}\right), 1.43$ (overlapped s, $\left.45 \mathrm{H}, \mathrm{C}_{5} \mathrm{Me}_{5}\right), 1.42$ (overlapped dd, $\left.18 \mathrm{H},{ }^{3} J_{\mathrm{HH}}=7.5 \mathrm{~Hz},{ }^{3} J_{\mathrm{HP}}=16.4 \mathrm{~Hz}, \mathrm{CH}_{3}\left({ }^{\mathrm{i}} \mathrm{Pr}\right)\right), 1.28\left(\mathrm{dd}, 18 \mathrm{H},{ }^{3} J_{\mathrm{HH}}=7.3 \mathrm{~Hz},{ }^{3} J_{\mathrm{HP}}=\right.$ $\left.13.9 \mathrm{~Hz}, \mathrm{CH}_{3}\left({ }^{\mathrm{i}} \mathrm{Pr}\right)\right) .{ }^{13} \mathrm{C}\left\{{ }^{1} \mathrm{H}\right\} \mathrm{NMR}\left(100 \mathrm{MHz}, \mathrm{CD}_{2} \mathrm{Cl}_{2}, 25^{\circ} \mathrm{C}\right) \delta: 152.1\left(\mathrm{~d},{ }^{2} J_{\mathrm{CP}}=7 \mathrm{~Hz}, \mathrm{C}_{2}\right), 144.2\left(\mathrm{~s}, \mathrm{C}_{1}\right)$, $130.6\left(\mathrm{~s}, \mathrm{CH}_{\mathrm{a}}\right), 119.2\left(\mathrm{~d},{ }^{3} J_{\mathrm{CP}}=5 \mathrm{~Hz}, \mathrm{CH}_{\mathrm{b}}\right), 94.8\left(\mathrm{~s}, \mathrm{C}_{5} \mathrm{Me}_{5}\right), 51.8\left(\mathrm{~s}, \mathrm{CCH}_{3}\right), 32.6\left(\mathrm{~d},{ }^{1} J_{\mathrm{CP}}=30 \mathrm{~Hz}, \mathrm{CH}\right.$ $\left.\left({ }^{\mathrm{i}} \mathrm{Pr}\right)\right), 31.4\left(\mathrm{~s}, \mathrm{CCH}_{3}\right), 20.0\left(\mathrm{~d},{ }^{2} J_{\mathrm{CP}}=4 \mathrm{~Hz}, \mathrm{CH}_{3}\left({ }^{\mathrm{i}} \mathrm{Pr}\right)\right), 18.2\left(\mathrm{~s}, \mathrm{CH}_{3}\left({ }^{\mathrm{i}} \mathrm{Pr}\right)\right), 9.7\left(\mathrm{~s}, \mathrm{C}_{5} M e_{5}\right) .{ }^{31} \mathrm{P}\left\{{ }^{1} \mathrm{H}\right\} \mathrm{NMR}$ (162 MHz, $\mathrm{CD}_{2} \mathrm{Cl}_{2}, 25^{\circ} \mathrm{C}$ ) $\delta: 108.5 \mathrm{ppm}$. Compound 6d. Anal. Calc. for $\mathrm{C}_{86} \mathrm{H}_{126} \mathrm{Cl}_{6} \mathrm{O}_{3} \mathrm{P}_{3} \mathrm{Ir}_{3}: \mathrm{C}, 49.42$; $\mathrm{H}, 6.08$. Found: $\mathrm{C}, 49.40 ; \mathrm{H}, 5.99 .{ }^{1} \mathrm{H}$ NMR $\left(400 \mathrm{MHz}, \mathrm{CDCl}_{3}, 25{ }^{\circ} \mathrm{C}\right) \delta: 7.25\left(\mathrm{~d}, 6 \mathrm{H},{ }^{3} \mathrm{~J}_{\mathrm{HH}}=9.1 \mathrm{~Hz}, \mathrm{H}_{\mathrm{b}}\right)$, $6.94\left(\mathrm{~d}, 6 \mathrm{H},{ }^{3} \mathrm{~J}_{\mathrm{HH}}=8.6 \mathrm{~Hz}, \mathrm{H}_{\mathrm{a}}\right), 3.11-2.92(\mathrm{~m}, 6 \mathrm{H}, \mathrm{CH}(\mathrm{Cy})), 2.78-2.62\left(\mathrm{~m}, 6 \mathrm{H}, \mathrm{CH}_{2}(\mathrm{Cy})\right), 2.11-1.97$ (overlapped $\mathrm{m}, 6 \mathrm{H}, \mathrm{CH}_{2}(\mathrm{Cy})$ ), 2.07 (overlapped s, $3 \mathrm{H}, \mathrm{CH}_{3}$ ), 1.89-1.06 (overlapped m, $46 \mathrm{H}, \mathrm{CH}_{2}$ (Cy)), 1.45 ppm (overlapped s, $\left.45 \mathrm{H}, \mathrm{C}_{5} \mathrm{Me}_{5}\right) .{ }^{13} \mathrm{C}\left\{{ }^{1} \mathrm{H}\right\} \mathrm{NMR}\left(100 \mathrm{MHz}, \mathrm{CDCl}_{3}, 25{ }^{\circ} \mathrm{C}\right) \delta: 151.5\left(\mathrm{~d},{ }^{2} J_{\mathrm{CP}}\right.$ $\left.=7 \mathrm{~Hz}, \mathrm{C}_{2}\right), 143.4\left(\mathrm{~s}, \mathrm{C}_{1}\right), 129.9\left(\mathrm{~s}, \mathrm{CH}_{\mathrm{a}}\right), 118.5\left(\mathrm{~d},{ }^{3} J_{\mathrm{CP}}=4 \mathrm{~Hz}, \mathrm{CH}_{\mathrm{b}}\right), 94.0\left(\mathrm{~s}, \mathrm{C}_{5} \mathrm{Me}_{5}\right), 51.1\left(\mathrm{~s}, \mathrm{CCH}_{3}\right)$, $43.3\left(\mathrm{~d},{ }^{1} J_{\mathrm{CP}}=29 \mathrm{~Hz}, \mathrm{CH}(\mathrm{Cy})\right), 30.9\left(\mathrm{~s}, \mathrm{CCH}_{3}\right), 29.3\left(\mathrm{~d},{ }^{3} J_{\mathrm{CP}}=3 \mathrm{~Hz}\right), 27.9\left(\mathrm{~d},{ }^{2} J_{\mathrm{CP}}=10 \mathrm{~Hz}, \mathrm{CH}_{2}(\mathrm{Cy})\right)$, $27.6\left(\mathrm{~s}, \mathrm{CH}_{2}(\mathrm{Cy})\right), 27.5\left(\mathrm{~d},{ }^{2} \mathrm{JCP}_{\mathrm{CP}}=14 \mathrm{~Hz}, \mathrm{CH}_{2}(\mathrm{Cy})\right), 26.7\left(\mathrm{~s}, \mathrm{CH}_{2}(\mathrm{Cy})\right), 9.2 \mathrm{ppm}\left(\mathrm{s}, \mathrm{C}_{5} \mathrm{Me} e_{5}\right) .{ }^{31} \mathrm{P}\left\{{ }^{1} \mathrm{H}\right\}$ $\mathrm{NMR}\left(162 \mathrm{MHz}, \mathrm{CDCl}_{3}, 25^{\circ} \mathrm{C}\right) \delta: 103.2 \mathrm{ppm}$.

Compound 7a. A dichloromethane $(5 \mathrm{~mL})$ solution of 1 a $(66.0 \mathrm{mg}, 0.08 \mathrm{mmol})$ was added at room temperature and under nitrogen atmosphere over a dichloromethane $(5 \mathrm{~mL})$ solution of $\left[\mathrm{Ru}(p \text {-cymene }) \mathrm{Cl}_{2}\right]_{2}(70.7 \mathrm{mg}, 0.23 \mathrm{mmol})$. The resulting solution was stirred for $1 \mathrm{~h}$. Then the solvent was concentrated under, vacuum pentane was added to afford the precipitation of a red solid, which was washed with pentane and diethyl ether. The resulting solid was passed through a pad of $\mathrm{SiO}_{2}$ in ethyl acetate to obtain $7 \mathrm{a}$ as a red powder $(93.2 \mathrm{mg}, 0.05 \mathrm{mmol}, 68 \%)$. Single crystals were obtained by slow diffusion of pentane into a $\mathrm{CH}_{2} \mathrm{Cl}_{2} /$ acetone solution $(3: 1)$ at $-30{ }^{\circ} \mathrm{C}$. Anal. Calc. for $\mathrm{C}_{86} \mathrm{H}_{87} \mathrm{Cl}_{6} \mathrm{O}_{3} \mathrm{P}_{3} \mathrm{Ru}_{3}$ : C, 58.11; $\mathrm{H}, 4.93$. Found: $\mathrm{C}, 57.97 ; \mathrm{H}, 4.92 .{ }^{1} \mathrm{H}$ NMR (400 MHz, $\mathrm{CDCl}_{3}, 25$ $\left.{ }^{\circ} \mathrm{C}\right) \delta: 8.05-7.92\left(\mathrm{~m}, 12 \mathrm{H}, o-\mathrm{C}_{6} \mathrm{H}_{5}\right), 7.39-7.28\left(\mathrm{~m}, 18 \mathrm{H}, m-\mathrm{C}_{6} \mathrm{H}_{5} ; p-\mathrm{C}_{6} \mathrm{H}_{5}\right), 7.08\left(\mathrm{~d}, 6 \mathrm{H},{ }^{3} \mathrm{~J}_{\mathrm{HH}}=8.5 \mathrm{~Hz}\right.$, $\left.\mathrm{H}_{\mathrm{b}}\right), 6.74\left(\mathrm{~d}, 6 \mathrm{H},{ }^{3} J_{\mathrm{HH}}=8.4 \mathrm{~Hz}, \mathrm{H}_{\mathrm{a}}\right), 5.29-5.22\left(\mathrm{~m}, 12 \mathrm{H}, \mathrm{H}_{\mathrm{c}}\right), 2.51\left(\mathrm{sept}, 3 \mathrm{H},{ }^{3} J_{\mathrm{HH}}=7.3 \mathrm{~Hz}, \mathrm{CH}\left({ }^{\mathrm{i}} \mathrm{Pr}\right)\right.$ (p-cymene)), $1.92\left(\mathrm{~s}, 3 \mathrm{H}, \mathrm{CCH}_{3}\right), 1.46\left(\mathrm{~s}, 9 \mathrm{H}, \mathrm{CH}_{3}\right.$ (p-cymene)), $0.83 \mathrm{ppm}\left(\mathrm{d}, 18 \mathrm{H},{ }^{3} \mathrm{~J}_{\mathrm{HH}}=6.9 \mathrm{~Hz}, \mathrm{CH}_{3}\right.$ (iPr) (p-cymene)). ${ }^{13} \mathrm{C}\left\{{ }^{1} \mathrm{H}\right\} \mathrm{NMR}\left(100 \mathrm{MHz}, \mathrm{CDCl}_{3}, 25^{\circ} \mathrm{C}\right) \delta: 151.2\left(\mathrm{~s}, \mathrm{C}_{2}\right), 144.2\left(\mathrm{~s}, \mathrm{C}_{1}\right), 136.3\left(\mathrm{~d},{ }^{1} J_{\mathrm{CP}}=\right.$ $48 \mathrm{~Hz}$, ipso- $\left.\mathrm{C}_{6} \mathrm{H}_{5}\right), 132.4\left(\mathrm{~d},{ }^{2} J_{\mathrm{CP}}=10 \mathrm{~Hz}, o-\mathrm{C}_{6} \mathrm{H}_{5}\right), 131.2\left(\mathrm{~s}, p-\mathrm{C}_{6} \mathrm{H}_{5}\right), 129.8\left(\mathrm{~s}, \mathrm{CH}_{\mathrm{a}}\right), 128.2\left(\mathrm{~d},{ }^{3} J_{\mathrm{CP}}=10\right.$ $\left.\mathrm{Hz}, m-\mathrm{C}_{6} \mathrm{H}_{5}\right), 120.3\left(\mathrm{~s}, \mathrm{CH}_{\mathrm{b}}\right), 110.4\left(\mathrm{~s}, \mathrm{C}_{3}\right), 97.2\left(\mathrm{~s}, \mathrm{C}_{4}\right), 92.2\left(\mathrm{~s}, \mathrm{CH}_{\mathrm{c}}\right), 87.6\left(\mathrm{~d},{ }^{2} \mathrm{~J}_{\mathrm{CP}}=5 \mathrm{~Hz}, \mathrm{CH}_{\mathrm{c}}\right), 51.2(\mathrm{~s}$, $\left.\mathrm{CCH}_{3}\right), 31.0\left(\mathrm{~s}, \mathrm{CCH}_{3}\right), 30.4$ (s, $\mathrm{CH}$ ( $\left.{ }^{\mathrm{i}} \mathrm{Pr}\right)\left(p\right.$-cymene)), 21.8 (s, $\mathrm{CH}_{3}\left({ }^{\mathrm{i}} \mathrm{Pr}\right)$ (p-cymene)), $17.6 \mathrm{ppm}\left(\mathrm{s}, \mathrm{CH}_{3}\right.$ (p-cymene)). ${ }^{31} \mathrm{P}\left\{{ }^{1} \mathrm{H}\right\} \mathrm{NMR}\left(121 \mathrm{MHz}, \mathrm{CDCl}_{3}, 25^{\circ} \mathrm{C}\right) \delta: 113.8 \mathrm{ppm}$. 


\section{Conclusions}

In summary, we have described the coordination chemistry of a new family of readily accessible trisphosphinite ligands by preparing a number of trimetallic complexes based on a range of late transition metal precursors (i.e., $\mathrm{Au}(\mathrm{I}), \mathrm{Ag}(\mathrm{I}), \mathrm{Cu}(\mathrm{I}), \mathrm{Ir}(\mathrm{III}), \mathrm{Rh}(\mathrm{III})$, and $\mathrm{Ru}(\mathrm{II})$ ). These ligands present a remarkable degree of conformational flexibility, as evinced by the X-ray structures of one of the free ligands and several of the trimetallic complexes. This contrasts with trisphosphines typically employed to construct supramolecular architectures, which rely on rigid backbones. Thus, trisphosphinites could offer unique features to design novel self-assembled structures and complement the still underdeveloped area of multidentate phosphines in the context of supramolecular chemistry. This work offers key information on the coordination ability of these systems that will be valuable for future work in that direction.

Supplementary Materials: The following are available online, Figure S1-S40: NMR spectra of new compounds, Figure S41: MS (ESI) of 6a, Table S1-S2: X-Ray Structural Data of new compounds.

Author Contributions: Investigation and methodology, J.M.-P., M.G.A. and M.D.F.-M.; X-ray data curation, E.Á. and C.M.; writing—original draft preparation, J.M.P. and J.C.; conceptualization, J.M.-P. and J.C.; supervision, J.C.; funding acquisition, J.C. All authors have read and agreed to the published version of the manuscript.

Funding: This research was funded by European Research Council (ERC Starting Grant, CoopCat, Project 756575), BBVA Foundation (Investigadores y Creadores Culturales 2016) and the Spanish Ministry of Science, Innovation and University (CTQ2017-92622-EXP).

Conflicts of Interest: The authors declare no conflict of interest.

\section{References}

1. Sweigers, G.F.; Malafetse, T.J. Classification of coordination polygons and polyhedra according to their mode of self-assembly. 2. Review of the literature. Coord. Chem. Rev. 2002, 225, 91-121. [CrossRef]

2. Caulder, D.L.; Raymond, K.N. Supermolecules by Design. Acc. Chem. Res. 1999, 32, 975-982. [CrossRef]

3. Stang, P.J. Molecular Architecture: Coordination as the Motif in the Rational Design and Assembly of Discrete Supramolecular Species-Self-Assembly of Metallacyclic Polygons and Polyhedra. Chem. Eur. J. 1998, 4, 19-27. [CrossRef]

4. Janiak, C. Engineering coordination polymers towards applications. Dalton Trans. 2003, 2781-2804. [CrossRef]

5. Chakrabarty, R.; Mukherjee, P.S.; Stang, P.J. Supramolecular coordination: Self-assembly of finite two- and three-dimensional ensembles. Chem. Rev. 2011, 111, 6810-6918. [CrossRef]

6. James, S.L. Phosphines as building blocks in coordination-based self-assembly. Chem. Soc. Rev. 2009, 38, 1744-1758. [CrossRef]

7. van Calcar, P.M.; Olmstead, M.M.; Balch, A.L. Self-assembly of metal complexes with cyclophane or polymeric chain structures about a 1,3,5-tris(diphenylphosphino)benzene core. Chem. Commun. 1996, 2597-2598. [CrossRef]

8. Zhang, J.Y.; Miller, P.W.; Nieuwenhuyzen, M.; James, S.L. Polar Self-Assembly: Steric Effects Leading to Polar Mixed-Ligand Coordination Cages. Chem. Eur. J. 2006, 12, 2448-2453; [CrossRef]

9. Miller, P.W.; Nieuwenhuyzen, M.; Charmant, J.P.H.; James, S.L. The cyclic "Silver-Diphos" motif [Ag2( $\mu$-diphosphine)2]2+ as a synthon for building up larger structures. Inorg. Chem 2008, 47, 8367-8379. [CrossRef]

10. Che, C.-M.; Yip, H.-K.; Yam, V.W.-W.; Cheung, P.-Y.; Lai, T.-F.; Shieh, S.-J.; Peng, S.-M. Spectroscopy, photoredox properties and X-ray crystal structures of triangular gold(I) and silver(I) phosphine complexes. J. Chem. Soc. Dalton Trans. 1992, 427-433. [CrossRef]

11. James, S.L.; Mingos, D.M.P.; White, A.J.P.; Williams, D.J. Anion-templated formation of a unique inorganic 'super-adamantoid' cage [Ag6(triphos)4(O3SCF3)4]2+ [triphos $=(\mathrm{PPh} 2 \mathrm{CH} 2) 3 \mathrm{CMe}]$. Chem. Commun. 1998, 2323-2324. [CrossRef]

12. Xu, X.; Nieuwenhuyzen, M.; James, S.L. A Nanoporous Metal-Organic Framework Based on Bulky Phosphane Ligands. Angew. Chem. Int. Ed. 2002, 41, 764-767. [CrossRef]

13. Lim, S.H.; Cohen, S.M. Self-Assembled Supramolecular Clusters Based on Phosphines and Coinage Metals: Tetrahedra, Helicates, and Mesocates. Inorg. Chem. 2013, 52, 7862-7872. [CrossRef] [PubMed] 
14. Bowyer, P.K.; Cook, V.C.; Gharib-Naseri, N.; Gugger, P.A.; Rae, A.D.; Sweigers, G.F.; Willis, A.C.; Zank, J.; Wild, S.B. Configurationally homogeneous diastereomers of a linear hexa(tertiary phosphine): Enantioselective self-assembly of a double-stranded parallel helicate of the type (P)-[Cu3(hexaphos)2](PF6)3. Proc. Natl. Acad. Sci. USA 2002, 99, 4877-4882. [CrossRef] [PubMed]

15. Xu, X.; Nieuwenhuyzen, M.; Chambers, M.; MacLean, E.; Teat, S.J.; James, S.L. Labile coordination dendrimers. Chem. Commun. 2002, 78-79. [CrossRef]

16. Hoy, R.; Lönnecke, P.; Hey-Hawkins, E. Selective formation of a two-dimensional coordination polymer based on a tridentate phospholane ligand and gold(I). Dalton Trans. 2018, 47, 14515-14520. [CrossRef]

17. Xu, X.; Nieuwenhuyzen, M.; Zhang, J.; James, S.L. Effect of Coordinating Solvents on Solution Speciation and the Crystallisation via ROP of a Triphos-Silver Coordination Cage. J. Inorg. Organomet. Polym. Mater. 2005, 15, 431-437. [CrossRef]

18. Wan, X.-K.; Yuan, S.-F.; Lin, Z.-W.; Wang, Q.-M. A Chiral Gold Nanocluster Au20 Protected by Tetradentate Phosphine Ligand. Angew. Chem. Int. Ed. 2014, 53, 2923-2926. [CrossRef]

19. Lin, R.; Yip, J.H.K.; Zhang, K.; Koh, L.L.; Wong, K.-Y.; Ho, K.P. Self-Assembly and Molecular Recognition of a Luminescent Gold Rectangle. J. Am. Chem. Soc. 2004, 126, 15852-15869. [CrossRef]

20. Gianneschi, N.C.; Masar, M.S.; Mirkin, C.A. Development of a Coordination Chemistry-Based Approach for Functional Supramolecular Structures. Acc. Chem. Res. 2005, 38, 825-837. [CrossRef]

21. Bardají, M.; Laguna, A.; Vicente, J.; Jones, P.G. Synthesis of Luminescent Gold(I) and Gold(III) Complexes with a Triphosphine Ligand. Inorg. Chem. 2001, 40, 2675-2681. [CrossRef] [PubMed]

22. Zhang, J.; Yang, Q.; Zhu, Y.; Liu, H.; Chi, Z.; Su, C.-Y. Tetraphenylethylene-based phosphine: Tuneable emission and carbon doixide fixation. Dalton Trans. 2014, 43, 15785-15790. [CrossRef] [PubMed]

23. Feng, J.; Yao, L.; Zhang, J.; Mu, Y.; Chi, Z.; Su, C.-Y. A luminescent silver-phosphine tetragonal cage based on tetraphenylethylene. Dalton Trans. 2016, 45, 1668-1673. [CrossRef] [PubMed]

24. Fernández, E.J.; Laguna, A.; López-de-Luzuriaga, J.M.; Monge, M.; Sánchez-Forcada, E. Different phosphorescent excited states of tetra- and octanuclear dendritic-like phosphine gold(I) thiolate complexes: Photophysical and theoretical studies. Dalton Trans. 2011, 40, 3287-3294. [CrossRef] [PubMed]

25. Ananthnag, G.S.; Mague, J.T.; Balakrishna, M.S. Self-Assembled Cyclophane-Type Copper(I) Complexes of 2,4,6-Tris(diphenylphosphino)-1,3,5-triazine and Their Catalytic Application. Inorg. Chem. 2015, 54, 10985-10992. [CrossRef] [PubMed]

26. Fernandez-Pérez, H.; Etayo, P.; Panossian, A.; Vidal-Ferran, A. Phosphine-Phosphinite and Phosphine-Phosphite Ligands: Preparation and Applications in Asymmetric Catalysis. Chem. Rev. 2011, 111, 2119-2176. [CrossRef] [PubMed]

27. Agbossou-Niedercorn, F.; Suisse, I. Chiral aminophosphine phosphinite ligands and related auxiliaries: Recent advances in their design, coordination chemistry, and use in enantioselective catalysis. Coord. Chem. Rev. 2003, 242, 145-158. [CrossRef]

28. Vicente, B.C.; Huang, Z.; Brookhart, M.; Goldman, A.S.; Scott, S.L. Reactions of phosphinites with oxide surfaces: A new method for anchoring organic and organometallic complexes. Dalton Trans. 2011, 40, 4268-4274. [CrossRef]

29. Huang, Z.; Brookhart, M.; Goldman, A.S.; Kundu, S.; Ray, A.; Scott, S.L.; Vicente, B.C. Highly Active and Recyclable Heterogeneous Iridium Pincer Catalysts for Transfer Dehydrogenation of Alkanes. Adv. Synth. Catal. 2009, 351, 188-206. [CrossRef]

30. Dulière, E.; Marchand-Brynaert, J. A Convenient Synthesis of p-Aminobenzyl-tris(hydroxymethyl)methane as Precursor of Solid-Supported Tripodal Ligands. Synthesis 2002, 1, 39-42. [CrossRef]

31. Hollatz, C.; Schier, A.; Schmidbaur, H. Self-assembly of tripodal tris(diphenylphosphinito)fluoroborate ligands in trinuclear gold(I) complexes Inorg. Chem. Commun. 1998, 1, 115-117. [CrossRef]

32. Puddephatt, R.J. Montreal Medal Award Lecture - Coordination chemistry of molecular bowls: Ligands and their complexes derived from resorcinarenes. Can. J. Chem. 2006, 84, 1505-1514. [CrossRef]

33. Eisler, D.J.; Puddephatt, R.J. Structures and Conformational Dynamics of Gold(I) Halide Complexes of Resorcinarene Tetraphosphinite Ligands. Inorg. Chem. 2003, 42, 6352-6365. [CrossRef] [PubMed]

34. Eisler, D.J.; Kirby, C.W.; Puddephatt, R.J. Tetraphosphinitoresorcinarene Complexes: Dynamic Clusters with Silver(I) and Copper(I) Halides. Inorg. Chem. 2003, 42, 7626-7634. [CrossRef]

35. Eisler, D.J.; Puddephatt, R.J. Tetraphosphinitoresorcinarene Complexes: Cationic Silver(I) and Copper(I) Halide Complexes as Mercurate(II) Anion Receptors. Inorg. Chem. 2003, 42, 8192-8202. [CrossRef] 
36. Karakhanov, E.A.; Kardasheva, Y.S.; Runova, E.A.; Terenina, M.V.; Shadrova, A.Y. Hydroformylation of olefins catalyzed by rhodium complexes with phosphinitecalix[4]arenes. Pet. Chem. 2007, 47, 340-344. [CrossRef]

37. Meriça, N.; Durapa, F.; Aydemira, M.; Baysalb, A. The application of tunable tridendate P-based ligands for the $\mathrm{Ru}(\mathrm{II})$-catalysed transfer hydrogenation of various ketones. Appl. Organometal. Chem. 2014, 28, 803-808. [CrossRef]

38. Christina, H.; McFarlane, E.; McFarlane, W. Polyphosphorus ligands-V. The synthesis, phosphorus-31 NMR spectra and conformations of the polykis(diphenylphosphino) benzens (Ph2P)nC6H6-n $(n=1-4)$. Polyhedron 1988, 7, 1875-1879. [CrossRef]

39. Rosa, P.; Debay, A.; Capes, L.; Chastanet, G.; Bousseksou, A.; Le Floch, P.; Létard, J.-F. Heat- and Light-Induced Spin Transition of an Iron(II) Polymer Containing the 1,2,4,5-Tetrakis(diphenylphosphanyl)benzene Ligand. Eur. J. Inorg. Chem. 2004, 3017-3019. [CrossRef]

40. Lim, S.H.; Su, Y.; Cohen, S.M. Supramolecular Tetrahedra of Phosphines and Coinage Metals. Angew. Chem. Int. Ed. 2012, 51, 5106-5109. [CrossRef]

41. Naik, S.; Kumaravel, M.; Mague, J.T.; Balakrishna, M.S. Novel Trisphosphine Ligand Containing 1,3,5-Triazine Core, [2,4,6-C3N3\{C6H4PPh2-p\}3]: Synthesis and Transition Metal Chemistry. Inorg. Chem. 2014, 53, 1370-1381. [CrossRef] [PubMed]

42. Ferrer, M.; Giménez, L.; Gutiérrez, A.; Lima, J.C.; Martínez, M.; Rodríguez, L.; Martín, A.; Puttreddye, R.; Rissanen, K. Polypyridyl-functionalizated alkynyl gold(i) metallaligands supported by tri- and tetradentate phosphanes. Dalton Trans. 2017, 46, 13920-13934. [CrossRef] [PubMed]

43. Rajanbabu, T.V. Phosphinite and Phosphonite Ligands. In Phosphorus(III) Ligands in Homogeneous Catalysis: Design and Synthesis; Kamer, P.C.J., van Leeuwen, P.W.N.M., Eds.; John Wiley \& Sons, Ltd.: Hoboken, NJ, USA, 2012. [CrossRef]

44. Cotton, F.A.; Murillo, C.A.; Yu, R.M. Deliberate synthesis of the preselected enantiomer of an enantiorigid molecule with pure rotational symmetry T. Dalton Trans. 2005, 3161-3165. [CrossRef] [PubMed]

45. Tabatabaei, R.; Dehghanpour, S.; Simpson, J.; Lipkowski, J. Self-assembly of chelating, bridging N, N, N donor ligands and $\mathrm{Cu}(\mathrm{I}), \mathrm{Cu}(\mathrm{II}), \mathrm{Cd}(\mathrm{II}), \mathrm{Hg}(\mathrm{II})$ : Molecular box versus coordination polymer. Polyhedron 2015, 89, 9-19. [CrossRef]

46. Mishra, R.; Ülker, E.; Karadas, F. One-Dimensional Copper(II) Coordination Polymeras an Electrocatalyst for Water Oxidation. Chem. Electro. Chem. 2017, 4, 75-80. [CrossRef]

47. Mishra, R.; Patil, B.; Karadas, F.; Y1lmaz, E. Bioinspired Copper Coordination Polymer Catalysts for Oxygen Reduction Reaction. Chem. Select 2017, 2, 8296-8300. [CrossRef]

48. Di Nicola, C.; Koutsantonis, G.A.; Pettinari, C.; Skelton, B.W.; Somers, N.; White, A.H. The structural definition of some novel adducts of stoichiometry CuX:dpex:MeCN (2:1:1)(n), X = (pseudo-) halogen, dppx $=\mathrm{Ph} 2 \mathrm{E}(\mathrm{CH} 2) \mathrm{xEPh} 2, \mathrm{E}=\mathrm{P}, \mathrm{As}, \mathrm{Sb}$. Inorg. Chim. Acta 2006, 359, 2159-2169. [CrossRef]

49. Balakrishna, M.S.; Suresha, D.; Kumara, P.; Mague, J.T. Synthesis and transition metal chemistry of a bridging diphosphinite, 1,4 bis(diphenylphosphinoxy)benzene. J. Organomet. Chem. 2011, 696, 3616-3622. [CrossRef]

50. Eisler, D.J.; Puddephatt, R.J. Tetraphosphinite Resorcinarene Complexes: Silver(I) Capsule Complexes. Inorg. Chem. 2005, 44, 4666-4678. [CrossRef]

51. Gunther, H. NMR Spectroscopy: Basic Principles, Concepts and Applications in Chemistry; Wiley-VCH: Hoboken, NJ, USA, 2013.

52. Janiak, C. A critical account on $\pi-\pi$ stacking in metal complexes with aromatic nitrogen-containing ligands. J. Chem. Soc. Dalton Trans 2000, 3885-3896. [CrossRef]

53. Suezawa, H.; Yoshida, T.; Umezawa, Y.; Tsuboyama, S.; Nishio, M. CH/ $\pi$ Interactions Implicated in the Crystal Structure of Transition Metal Compounds-A Database Study. Eur. J. Inorg. Chem. 2002, 2002, 3148-3155. [CrossRef]

54. Braga, D.; Grepioni, F.; Tedesco, E. X-H- $\pi(X=\mathrm{O}, \mathrm{N}, \mathrm{C})$ Hydrogen Bonds in Organometallic Crystals. Organometallics 1998, 17, 2669-2672. [CrossRef]

55. Campos, J.; Esqueda, A.C.; Carmona, E. Cyclometallation and Hydrogen/Deuterium Exchange Reactions of an Arylphosphine Ligand upon Coordination to $\{\operatorname{Ir}(\eta 5-C 5 M e 5)\}$. Chem. Eur. J. 2010, 16, 419-422. [CrossRef] [PubMed]

56. Campos, J.; López-Serrano, J.; Álvarez, E.; Carmona, E. Cationic Ir(III) Alkylidenes Are Key Intermediates in C-H Bond Activation and C-C Bond-Forming Reactions. J. Am. Chem. Soc. 2012, 134, 7165-7175. [CrossRef] 
57. Campos, J.; Espada, M.F.; López-Serrano, J.; Carmona, E. Cyclometalated Iridium Complexes of Bis(Aryl) Phosphine Ligands: Catalytic C-H/C-D Exchanges and C-C Coupling Reactions. Inorg. Chem. 2013, 52, 6694-6704. [CrossRef] [PubMed]

58. Campos, J.; Carmona, E. Rhodium and Iridium Complexes of Bulky Tertiary Phosphine Ligands. Searching for Isolable Cationic MIII Alkylidenes. Organometallics 2015, 34, 2212-2221. [CrossRef]

59. Uson, R.; Laguna, A.; Laguna, M.; Briggs, D.A.; Murray, H.H.; Fackler, J.P. (Tetrahydrothiophene)Gold(I) or Gold(III) Complexes. Inorg. Synth. 1989, 26, 85-91. [CrossRef]

60. White, C.; Yates, A.; Maitlis, P.M.; Heinekey, D.M. (†5-Pentamethylcyclopentadienyl)Rhodium and -Iridium Compounds. Inorg. Synth. 1992, 29, 228-234. [CrossRef]

61. Bennett, M.A.; Huang, T.N.; Matheson, T.W.; Smith, A.K.; Nickerson, W. (ฤ6-Hexamethylbenzene) ruthenium Complexes. Inorg. Synth. 1982, 21, 74-78. [CrossRef]

Sample Availability: Samples of the compounds 1a-7a are available from the authors.

(C) 2020 by the authors. Licensee MDPI, Basel, Switzerland. This article is an open access article distributed under the terms and conditions of the Creative Commons Attribution (CC BY) license (http://creativecommons.org/licenses/by/4.0/). 